\title{
Do the Securities Laws Matter? The Rise of the Leveraged Loan Market
}

\author{
Elisabeth de Fontenay*
}

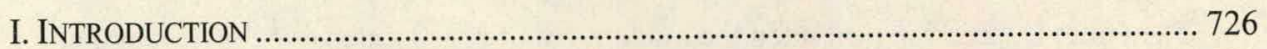

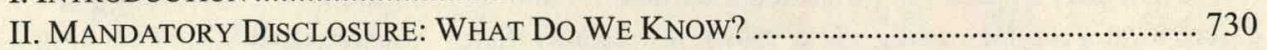

A. Empirical Testing: Technical Concerns ........................................................ 730

B. Empirical Testing: Doctrinal Concerns-The Benefits and Costs of

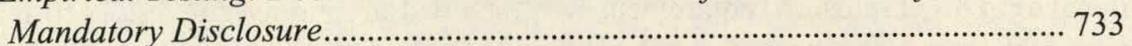

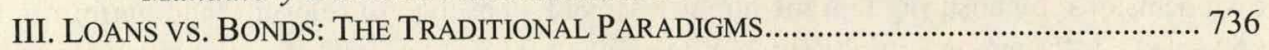

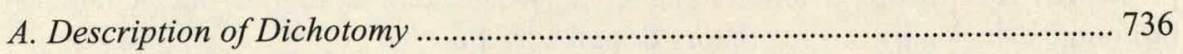

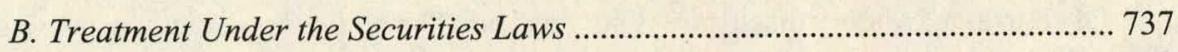

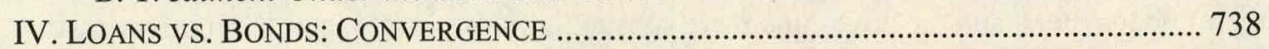

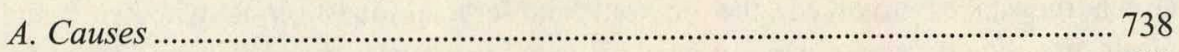

1. Changes to the Loan Market .................................................................... 738

2. Changes to the Bond Market ....................................................................... 741

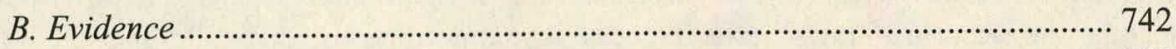

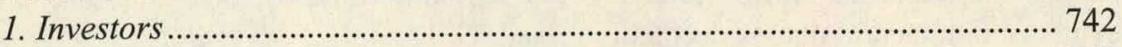

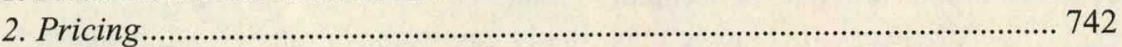

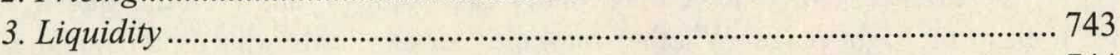

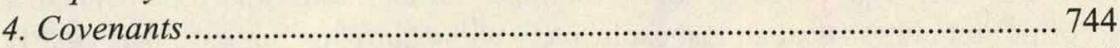

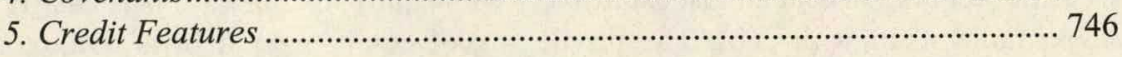

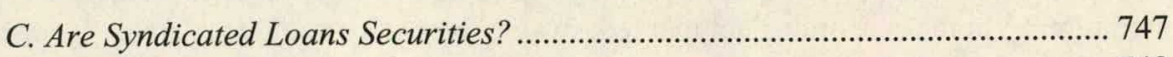

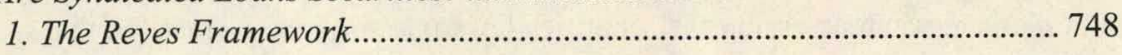

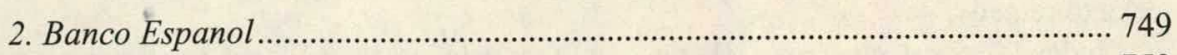

3. Reves Applied to Syndicated Loans............................................................ 752

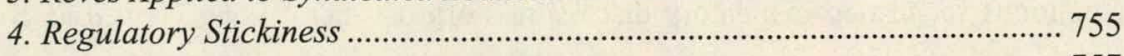

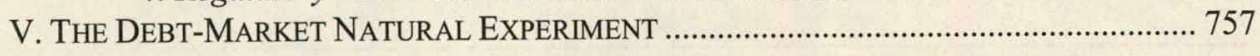

A. Natural Experiment ….................................................................................... 757

B. How We Got Here and What to Do About It ................................................ 759

1. Why the Leveraged Loan Market? ............................................................ 760

2. Why the High-Yield Bond Market? .......................................................... 763

* Associate Professor, Duke University School of Law. For comments and suggestions, thanks are due to Matt Adler, Jamie Boyle, Bill Bratton, Sam Buell, James Coleman, Jim Cox, Lisa Fairfax, Theresa Gabaldon, Mitu Gulati, Joan Heminway, Donald Langevoort, Jeffrey Manns, Ralf Michaels, Steven Schwarcz, Anne Tucker, Art Wilmarth, and workshop participants at Duke and at the 2014 C-LEAF Junior Faculty Business and Financial Law Workshop at The George Washington University Law School. Peter Bang and Brittany Edwards-Franklin provided excellent research assistance. All errors are mine. 


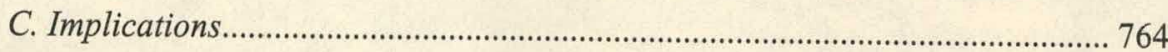

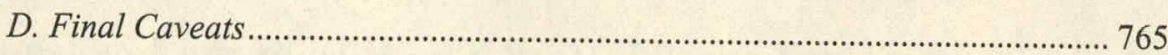

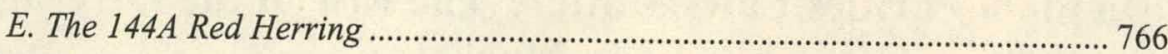

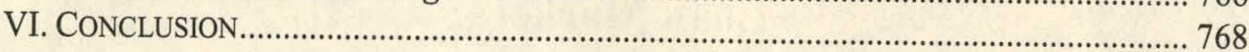

\section{INTRODUCTION}

The Great Depression prompted the modern era of broad, intensive federal regulation of corporate capital raising. The crown jewel and major innovation of this regulatory regime was mandatory disclosure-the requirement that issuers of securities disclose specific information to the public, both upon issuance and on an ongoing basis postissuance. This disclosure requirement was intended to empower investors to make their own decisions, by ensuring that the public received a baseline of relevant (and uniformly presented) information from issuing companies. ${ }^{1}$ U.S. corporate financing has been profoundly shaped by this regulatory design ever since.

Of course, mandatory disclosure is not costless. The direct transaction costs to issuers, their underwriters, and the government are substantial, to say nothing of the indirect costs. ${ }^{2}$ Given the stakes involved, the obvious and crucial question is whether mandatory disclosure actually works. Does it even achieve the goals ascribed to it, and if so, do these benefits outweigh the associated costs? After more than eight decades of federal securities regulation, the answers to these questions remain surprisingly elusive. It turns out that testing the securities laws' effectiveness is extraordinarily difficult, and the limited evidence obtained to date is decidedly mixed.

This Article asserts that we may finally gain some purchase on this question-if only we look in the right place. Whether implicitly or explicitly, discussions of the merits of securities regulation deal almost exclusively with equity instruments, particularly common stock, rather than with debt. The privileging of equity over debt is ubiquitous in the literature. ${ }^{3}$ Yet the corporate debt markets swamp the equity markets in size. ${ }^{4}$ Ignoring the debt markets when assessing the securities laws is a surprising omission that this Article seeks to remedy.

Indeed, recent sweeping changes in the debt markets have created near-perfect conditions for testing mandatory disclosure's effectiveness. Long viewed as contrasting

1. Mandatory disclosure thus stands in stark contrast to government agencies' substantive review of investment opportunities, which until then had been the states' predominant form of securities regulation. See Frank H. Easterbrook \& Daniel R. Fischel, Mandatory Disclosure and the Protection of Investors, 70 VA. L. REV. $669,669-70$ (1984) (contrasting the federal disclosure regime with the substantive regulation of investments).

2. See infra Part II.B (discussing the costs and benefits of mandatory disclosure).

3. In discussions of the securities laws, this predilection for equity over debt is explained by the fact that equity securities are riskier overall, and retail direct investors still hold a meaningful share of the stock market. See infra note 88 (dealing with the near-complete absence of direct retail investors from the corporate debt markets).

4. In 2006 alone, the total amount of corporate debt issuances exceeded $\$ 1$ trillion, compared to only $\$ 152$ billion in equity issuances. Hendrik Bessembinder \& William Maxwell, Markets: Transparency and the Corporate Bond Market, 22 J. ECON. PERSP. 217, 219 (2008). 
forms of debt, the markets for large corporate loans (referred to as syndicated loans) and corporate bonds are rapidly converging into a single asset class. ${ }^{5}$ Yet bonds are treated as securities under the federal securities laws, while loans are not. The existence of two functionally equivalent markets, one regulated and the other unregulated, amounts to a natural experiment testing the federal securities laws' effects on the largest source of corporate financing, the corporate debt markets. Though the convergence is as yet incomplete, it is enough to make the longstanding regulatory distinction between the two untenable under existing doctrine.

That bonds and loans are now virtually interchangeable is nothing short of remarkable. In the canons of corporate finance, the two instruments have historically been at opposite ends of the debt spectrum. ${ }^{6}$ Corporate bonds were typically understood as long-term, passive investments in blue-chip corporations. Bank loans, on the other hand, were shortterm extensions of credit most suited to small, opaque companies requiring intensive monitoring by the creditor. Bonds were thus appropriate for dispersed, unsophisticated retail investors, and were highly liquid instruments (that is, readily tradable). By contrast, loans were funded nearly exclusively by banks, which specialized in credit analysis, had the ability and incentives to monitor their borrowers closely, and were themselves tightly regulated entities. Because of the steep information costs associated with these loans, they were typically held to maturity by the bank that funded them, and thus plainly illiquid. These fundamental differences between bonds and loans in the nature and type of their creditors, their liquidity, and the information required by creditors justified the treatment of bonds as securities and loans as non-securities.

Yet dramatic changes to the corporate loan market have converted it into something closely akin to the bond market. ${ }^{7}$ Changes in both supply and demand have radically altered the fundamental nature of corporate loans, transforming them into instruments that can be traded by passive investors. Large corporate loans are no longer funded and held to maturity by a single bank, but instead are syndicated to large groups of creditors and subsequently traded to reach still other creditors. More surprising still, banks represent only a small minority of such creditors. The outcome of this rapid and dramatic metamorphosis of the loan market is a new capital market that is both deep and highly liquid. The convergence of the bond and loan markets is particularly striking at the riskiest end of the spectrum in each. High-yield (or "junk") bonds and leveraged loans refer to the bonds and syndicated loans, respectively, of companies with high ratios of debt to equity in their capital structure. Leveraged loans and high-yield bonds currently feature strikingly similar pricing, non-price terms, participants, and liquidity.

Unless and until the loan and bond markets become perfectly interchangeable (save for their regulation), the conclusions drawn from this natural experiment will necessarily be tentative. Yet, based solely on the convergence exhibited thus far, we may already derive a crucial result: the very existence of a liquid corporate loan market suggests that the

5. See infra Part IV (discussing the convergence of loans and bonds).

6. See infra Part III (discussing the opposing paradigms of loans and bonds).

7. See infra Part IV (discussing the convergence of loans and bonds). 
securities laws ${ }^{8}$ are not doing the work for which they were intended. Consider the two bedrock goals of mandatory disclosure under the federal securities laws: (1) protecting unsophisticated investors, ${ }^{9}$ and (2) remedying the underproduction of material investment information. ${ }^{10}$ The first goal is simply inapplicable in today's debt markets, because both the corporate loan and corporate bond markets are, for all intents and purposes, purely institutional. ${ }^{11}$ Retail investors have always been absent from the corporate loan market, and recently have all but disappeared from the corporate bond market. ${ }^{12}$ Concerns about protecting individuals who cannot absorb losses are thus allayed in these markets.

The second goal requires some elaboration. The currently dominant theory supporting mandatory disclosure holds that, left to their own devices, companies lack incentives to provide investors with sufficient information, and investors lack incentives to pay for it, due to now familiar free-riding and collective action problems. Armed with too little reliable information, rational investors in an unregulated market will invest less than is efficient - a bad outcome for both investors and issuers. Requiring issuers to disclose material information to the public could thus increase the volume of investment in a market to something closer to its optimal level. In this view, mandatory disclosure is not a burden on investment (as issuers frequently lament), but rather a necessary condition to robust investment.

Unfortunately, the convergence of the loan and bond markets to date strongly suggests that this second aim of securities regulation is unrealized in the corporate debt markets: mandatory disclosure cannot be a necessary condition to developing a deep and liquid market, simply because the unregulated leveraged loan market, in which disclosure to

8. Throughout this Article, references to "securities regulation" or "securities laws" refer solely to the mandatory disclosure rules imposed on securities' issuers (including for these purposes antifraud liability), rather than to other areas of securities regulation, i.e., the regulation of tender offers, shareholder voting, broker-dealers, and mutual funds, market transparency for trades, and, more recently, the regulation of corporate governance and executive compensation under Sarbanes-Oxley and Dodd-Frank.

9. See H.R. REP. No. 73-1383, at 5 (1934) ("[I]t becomes a condition of the very stability of . . . society that its rules of law ... protect [the] ordinary citizen's dependent position."); H.R. REP. No. 73-85, at 2 (1933) (stating that "[t]he purpose of [the Securities Act of 1933] . . . is to protect the public with the least possible interference to honest business."); see generally JOEL SELIGMAN, THE TRANSFORMATION OF WALL STREET: A HISTORY OF THE SECURITIES AND EXCHANGE COMMISSION AND MODERN CORPORATE FINANCE (3d ed. 2003) (summarizing the views of proponents and legislators at the time the Securities Acts were enacted).

10. As a practical matter, the securities laws do not always result in issuers producing more, or more frequent, information. They often restrict, or at a minimum delay, the information flow from companies to the market, most notably in the pre-IPO period. See, e.g., Nemit Shroff et al., Voluntary Disclosure and Information Asymmetry: Evidence from the 2005 Securities Offering Reform, 51 J. ACCT. RES. 1299, 1299 (2013) (finding that information released to the market actually increased following relaxation of the SEC's gun-jumping rules in 2005). Given that mandatory disclosure may in fact limit information flow to the market, critiques of mandated disclosure that rest on the problem of information overload to consumers might be misplaced. See, e.g., Omri Ben-Shahar \& Carl E. Schneider, The Failure of Mandated Disclosure, 159 U. PA. L. REV. 647, 651 (2011) (characterizing mandatory disclosure to consumers as being based on the false premise that "more information is better than less"); Susanna Kim Ripken, The Dangers and Drawbacks of the Disclosure Antidote: Toward a More Substantive Approach to Securities Regulation, 58 BAYLOR L. REV. 139, 160-63 (2006) (describing how securities regulation exacerbates information overload).

11. See infra note 88 and accompanying text (discussing the decrease in the proportion of direct retail investors).

12. Id. 
investors is limited, non-uniform, and purely voluntary, is now significantly larger than the regulated high-yield bond market. ${ }^{13}$ Purely through private ordering, the loan market appears to be providing sufficient information for investors to treat syndicated loans as they do bonds - that is, as largely passive investments that do not require intensive monitoring on their part. In summation, this implies that the securities laws are not achieving their principal goal in the markets for corporate debt.

Admittedly, this sweeping conclusion is unlikely to be well received in a world still scarred by the recent financial crisis. Yet, its normative implications are comparatively mild. Despite the near equivalence of the two markets, issuers have not migrated wholesale from the regulated high-yield bond market to the unregulated syndicated loan market; for the time being, the two markets exist side-by-side. Thus, even if securities regulation is unnecessary for robust investment in the corporate debt markets, it is also unlikely to truly impede investment - the institutional structures to support mandated disclosure are already in place, and investors such as mutual funds are still required to invest some portion of their assets in registered securities. The securities laws applicable to corporate debt may not be effective, yet nor do they appear terribly harmful. The latter point may explain why the regulatory dichotomy between the corporate loan and bond markets persists to this day, despite its now glaring lack of grounding: securities regulators may be tacitly (and cynically) acknowledging that, whether they treat leveraged loans as securities or not, the decision is unlikely to matter.

However, this Article's skepticism about securities regulation in the debt markets merits a word of caution. The fact that mandatory disclosure is proving superfluous in the corporate debt markets certainly does not mean that the debt markets raise no regulatory concerns. Debt-fueled investment bubbles are particularly worrisome: when the bubble bursts and corporate credit suddenly dries up, as it did most dramatically during the Great Depression and most recently from 2007-2009, the ripple effects are felt throughout the economy, eventually harming "Main Street". workers and consumers. Far from advocating a hands-off approach to the debt markets, this Article merely suggests that mandatory disclosure is not (or is no longer) remedying the information failures for which it was designed and has little or no bearing on regulators' most pressing concern: systemic risk. ${ }^{14}$ In fact, while leveraged loan investors suffered steep losses in the recent financial crisis, high-yield bond investors' losses were steeper, in spite of the securities laws' protections. ${ }^{15}$

13. In 2012 , leveraged loan market issuances reached $\$ 664$ billion, compared to $\$ 327$ billion in high-yield bond issuances. Ioana Barza, Press Release, 2012 U.S. High Yield Capital Markets Reach All-Time \$991B Record, Thomson Reuters LPC (Apr. 19, 2014, 8:50 PM), https://www.loanpricing.com/2013/01/2012-u-s-highyield-capital-markets-reach-all-time-991b-record/.

14. See Steven L. Schwarcz, Systemic Risk, 97 GEO. L.J. 193, 204 (2008) (defining systemic risk as "the risk that (i) an economic shock . . . triggers (through a panic or otherwise) either (X) the failure of a chain of markets or institutions or $(\mathrm{Y})$ a chain of significant losses to financial institutions, (ii) resulting in increases in the cost of capital or decreases in its availability ..."); see also Donald C. Langevoort \& Robert B. Thompson, "Publicness" in Contemporary Securities Regulation After the JOBS Act, 101 GEO. L.J. 337, 337 (2013) (recognizing "the public's interest in a safe and stable financial system" as a key driver of securities regulation).

15. At the peak of U.S. corporate debt defaults in the fourth quarter of 2009 , the leveraged loan default rate reached approximately $12 \%$, compared to approximately $16 \%$ in the high-yield bond market. Alicia Sansone et al., Investing in Loans Through the Cycles, LOAN SYNDICATIONS \& TRADING ASs'N, 4 (2013), available at http://www.lsta.org/WorkArea/showcontent.aspx?id=16749. 
When the debt markets crash again - which they inevitably will - the presence or absence of mandatory disclosure will not be the difference-maker.

This Article proceeds as follows. Part II briefly surveys the largely inconclusive empirical studies on the effectiveness of mandatory disclosure. Parts III through V offer a different approach to assessing securities regulation in the debt markets. Specifically, Part III describes the traditional opposing paradigms of corporate bonds and corporate loans that long justified their status under the federal securities laws as securities and nonsecurities, respectively. Part IV identifies recent sweeping changes in the corporate loan market that have caused it to converge rapidly with the bond market, putting tremendous pressure on the two markets' differing regulatory treatment. Part $V$ first describes how this convergence creates a natural experiment testing the effectiveness of the securities laws in the debt markets. With both issuers and investors increasingly viewing these two liquid markets - one regulated, the other not-as substitutes, ${ }^{16}$ the securities laws applicable to corporate debt appear to be having little beneficial effect. Part V then concludes by addressing policy implications.

\section{MANDATORY DISCLOSURE: WHAT DO WE KNOW?}

\section{A. Empirical Testing: Technical Concerns}

Capital, like all good things in this world, is scarce. Firms compete with one another for it, and convincing investors to part with their money for a time is no simple matter. A firm's value is not readily observable or verifiable by investors. Some level of corporate disclosure is therefore necessary to entice wary investors and to achieve an efficient allocation of capital among firms. ${ }^{17}$ This much is clear. Less clear is whether such disclosure ought to be mandated, as it is currently for issuers of "securities" under federal law, or purely voluntary.

Testing whether mandatory disclosure actually works has been a tantalizing possibility since the halcyon days of U.S. securities regulation in the 1930 s. Yet despite 80 years of broad, intensive securities regulation, we appear little closer to a conclusive, empirically grounded result. It is safe to say that there is widespread agreement on two seemingly conflicting points: (1) empirical testing of the securities laws is a worthy and, in fact, crucial pursuit, and (2) such testing is plagued with conceptual and practical difficulties that have rendered the results largely inconclusive. This section briefly reviews the most salient empirical studies of mandatory disclosure and their critiques. ${ }^{18}$ Except

16. See Bessembinder \& Maxwell, supra note 4, at 230 (describing syndicated loans as "a substitute for corporate bonds"); Arthur E. Wilmarth, Jr., The Transformation of the U.S. Financial Services Industry, 19752000: Competition, Consolidation, and Increased Risks, 2002 U. ILL. L. REV. 215, 379 (2002) (noting that borrowers often view syndicated loans and bonds as substitutes); Yener Altunbas et al., Large Debt Financing: Syndicated Loans Versus Corporate Bonds (European Central Bank, Working Paper No. 1028, 2009), available at papers.ssm.com/so13/papers.cfm?abstract_id=1349667 (referring to the syndicated loan market as "the most powerful substitute to the corporate bond markets" in the eurozone).

17. Paul M. Healy \& Krishna G. Palepu, Information Asymmetry, Corporate Disclosure, and the Capital Markets: A Review of the Empirical Disclosure Literature, 31 J. AccT. \& ECON. 405, 406 (2001).

18. See generally Anne Beyer et al., The Financial Reporting Environment: A Review of the Recent Literature, 50 J. ACCT. \& ECON. 296 (2010) (reviewing in detail the empirical literature on mandatory disclosure). 
where noted, mandatory disclosure as used in this Article refers to required disclosures at issuance of a security (such as the registration statement for an initial public offering), ${ }^{19}$ and the ongoing, periodic disclosure by large issuers (such as $8-\mathrm{K}, 10-\mathrm{Q}$, and $10-\mathrm{K}$ filings), ${ }^{20}$ as well as to federal antifraud liability applied to issuers of securities and their underwriters. ${ }^{21}$

In randomized drug trials - the gold standard for testing a treatment's effectivenessthe outcomes of the treatment group are compared to those of a control group, with patients randomly assigned to one of the two groups. The desired outcome-improvement in the patient's treated condition - is clearly specified and measurable. When mandatory disclosure is the "treatment" to be tested, however, we quickly depart from the drug-trial ideal. Certain difficulties are common to all empirical testing of regulation, and indeed to all empirical testing in the social sciences, but some are particular to, or exacerbated in, the context of securities regulation.

For one thing, we lack a true control group. ${ }^{22}$ One could imagine a new disclosure rule applying only to half of all public companies, with those subjected to the law determined by lottery or a random number generator. While empiricists would no doubt welcome such an optimized research design, obvious political concerns preclude the possibility. Instead, securities laws apply to all companies, transactions, or actors satisfying certain criteria, leaving no control group for empirical testing.

An alternative approach is to use the unregulated group most closely resembling the regulated group as an ersatz control group. But of course, by definition the regulated and unregulated groups have different ex ante characteristics, they are taken from different samples, making any conclusions speculative. For example, municipal bonds, which are exempt from mandatory disclosure, are often touted as a true counterpoint to (regulated) corporate bonds. ${ }^{23}$ But the two markets cover very different types of issuers: governmental

In addition to the empirical projects reviewed in this Article, there is a considerable body of work testing the Sarbanes-Oxley Act's effects. Because the latter imposed additional disclosure obligations as well as significant corporate governance-related changes on public companies, this literature is less useful in isolating the specific impact of mandatory disclosure.

19. 15 U.S.C. $\$ 77 \mathrm{e}(\mathrm{c})(2012)$.

20. 15 U.S.C. $\S 78$ o(d) (2012).

21. This Article takes the somewhat unusual approach of grouping together under the rubric "mandatory disclosure" (i) the specific disclosure rules for securities registration under the Securities Act of 1933 [hereinafter, the '33 Act], (ii) the on-going disclosure obligations for certain large issuers under the Securities Exchange Act of 1934 [hereinafter, the '34 Act], and (iii) the antifraud provisions applicable to securities issuers and underwriters under Sections 11 and 12(a)(2) of the ' 33 Act and Rule 10b-5 of the '34 Act. Rule 10b-5, for example, though styled as an enforcement mechanism, functionally amounts to an additional information disclosure requirement. By rendering issuers liable for failing to disclose material information if omitting to do so would be misleading, Rule 10b-5 sets a floor on the information disclosed to investors and sets a standard ("materiality") for its content. While the ' 33 Act and '34 Act mandatory disclosure provisions differ in approach from Rule 10b- 5 by specifically listing the information to be disclosed and mandating its format, at base all three sets of provisions mandate the production of material information by issuers for the benefit of investors.

22. This problem is not specific to securities regulation, but is common to virtually all empirical testing in the social sciences.

23. See, e.g., John C. Coffee, Jr., Market Failure and the Economic Case for a Mandatory Disclosure System, 70 VA. L. REV. 717, 744 46 (1984) (discussing obtaining "an inferential understanding of the impact of mandatory disclosure" by looking "at the differences between the disclosure level within the public securities 
entities versus for-profit companies. Investors may well require significantly different disclosure from municipalities than from private corporations, making any comparison between the two groups tenuous.

A second-best approach to the pure drug-trial method is to compare the before-andafter results of introducing regulation solely for the treatment group. This "event study" approach is taken by the vast majority of empirical studies of securities regulation. ${ }^{24}$ In his seminal, though much criticized 1964 work, George Stigler compared the abnormal returns and variance in returns of newly public companies from a pre-Depression period to those in a post-Depression (and therefore post-mandatory disclosure) period. ${ }^{25} \mathrm{He}$ found no difference in return results between the two groups and a reduction in variance in the postregulation group. On this basis, Stigler concluded that securities regulation had provided no benefit to investors and had had the unfortunate side-effect of excluding small companies from the market altogether. ${ }^{26}$

Unfortunately, the event study approach typically suffers from two major defects: (1) the endogeneity of securities regulation effects, and (2) the duration and complexity of the regulatory process. ${ }^{27}$ The first problem exists because changes in securities regulation typically arise in response to significant changes in the markets (such as financial crises, technological or financial innovation, etc.), complicating the task of isolating the effects of securities regulation from other changes to the markets. Most notoriously, Stigler's finding of a reduction in stock-return variance following the birth of mandatory disclosure could equally well be explained by the Great Depression itself, which put many high-risk, opaque firms out of existence. The lengthy and complex regulatory process also complicates empirical testing. Markets may react to potential legislation well before it is enacted, making it difficult to pinpoint the correct "before" and "after" periods to isolate for comparison. ${ }^{28}$ Due to these imperfections in research design, commentators have relied on

market subject to the SEC regulation and the level that prevails within the one major securities market that is exempt from registration-the municipal bond market").

24. See generally George J. Benston, Required Disclosure and the Stock Market: An Evaluation of the Securities Exchange Act of 1934, 63 AM. ECON. REV. 132 (1973) (examining the effects of the '34 Act's financial disclosure requirements); Carol J. Simon, The Effect of the 1933 Securities Act on Investor Information and the Performance of New Issues, 79 AM. ECON. REv. 295, 313 (1989) (examining the effects of the '33 Act on firms' stock returns); George J. Stigler, Public Regulation of the Securities Markets, 37 J. Bus. 117, 120 (1964) (examining the effects on new-issue stock returns before and after the SEC imposed mandatory disclosure). For more recent work in this area, see generally Brian J. Bushee \& Christian Leuz, Economic Consequences of SEC Disclosure Regulation: Evidence from the OTC Bulletin Board, 39 J. ACCT. \& ECON. 233 (2005), examining firmspecific consequences of the SEC's disclosure regulations on previously unregulated market segments.

25. Stigler, supra note 24 , at 122.

26. Id. at 124 .

27. J. Harold Mulherin, Measuring the Costs and Benefits of Regulation: Conceptual Issues in Securities Markets, 13 J. CORP. FIN. 421, 424 (2007).

28. Alan Ferrell seems to have avoided this endogeneity problem in his study of the 1964 imposition of ' 34 Act mandatory disclosure on companies whose stock traded on the over-the-counter (OTC) market. See generally Allen Ferrell, Mandatory Disclosure and Stock Returns: Evidence from the over-the-Counter Market, 36 J. LEGAL STUD. 213 (2007). Fortuitously, the legislative change occurred at a time of relative calm in the markets. Id. Ferrell interprets his findings of a reduction in volatility and positive abnormal stock returns as suggesting that mandatory disclosure did provide investors some benefit. Id. 
the very same empirical studies to reach opposing conclusions as to the securities laws' effectiveness. ${ }^{29}$

A final approach, of more recent vintage, is the cross-sectional regression analysis of securities regulation's effects (and particular components thereof) on the development of a country's stock market. Problems with this multi-country regression analysis include the limited number of data points ${ }^{30}$ and, perhaps more troubling, the inherent ambiguity in the direction of causation: do features such as mandatory disclosure explain the success of a country's securities markets, or is it the other way around $?^{31}$

\section{B. Empirical Testing: Doctrinal Concerns - The Benefits and Costs of Mandatory Disclosure}

Beyond these sampling and technical difficulties, the considerable uncertainty regarding both the desired outcome and the possible side effects of the treatments to be measured and modeled hamper empirical studies. Empirical testing of securities regulation requires an economic theory of regulation - usually falling within either the public-interest or the special-interest ${ }^{32}$ framework - as this framing determines the hypotheses to be tested, the interpretation of the results, the burden of proof, the statistical power, and the captured unintended consequences. ${ }^{33}$ What, then, are the benefits that the securities laws aim to achieve, and what are their costs?

The securities laws' possible benefits ${ }^{34}$ have been variously described. They include: preventing unsophisticated investors from making risky investments, ${ }^{35}$ ensuring that

29. See Roberta Romano, Empowering Investors: A Market Approach to Securities Regulation, 107 YALE L.J. 2359, 2376 (1998) (relying on both Stigler and Benston for her claim that mandatory disclosure is not effective); see Merritt B. Fox, Retaining Mandatory Securities Disclosure: Why Issuer Choice is Not Investor Empowerment, 85 VA. L. REV. 1335 (1999) (reaching the opposite conclusion by critiquing Stigler, Benston, and Simon); see also Ronald J. Gilson \& Reinier H. Kraakman, The Mechanisms of Market Efficiency, 70 VA. L. REV. 549, 636-38 (1984) (critiquing Benston's conclusion that the 34 Act's lack of impact on stock prices demonstrated that the legislation had no beneficial effects).

30. The most frequently cited study, by La Porta et al., includes only 49 countries. See Rafael La Porta et al., What Works in Securities Laws?, 61 J. FIN. 1, 5 (2006).

31. Id. at 14. Other more technical criticisms of the approach taken in the La Porta, Lopez-de-Silanes \& Shleifer study involve (i) the construction of its indices and (ii) its reliance on the law on the books, rather than as applied or circumvented over time by judges and practitioners. See, e.g., Howell E. Jackson \& Mark J. Roe, Public and Private Enforcement of Securities Laws: Resource-Based Evidence, 93 J. FIN. ECON. 207, 209-10 (2009) (describing the problems with authority-based enforcement indexes); Paul G. Mahoney, The Development of Securities Law in the United States, 47 J. ACCT. RES. 325, 326 (2009) (stressing the distinction between law as enacted and law as applied); Holger Spamann, The "Antidirector Rights Index" Revisited, 23 REV. FIN. STUD. 467, 470-72 (2010) (critiquing the construction of the La Porta et al. index).

32. See Richard A. Posner, Theories of Economic Regulation, 5 Bell J. ECON. \& MGMT. SCI. 335, 343 (1974) (describing the special-interest theory of regulation).

33. Mulherin, supra note 27 , at 421-22.

34. See Theresa A. Gabaldon, The Disclosure of Preliminary Merger Negotiations as an Imperfect Paradigm of Rule 10b-5 Analysis, 62 N.Y.U. L. REV. 1218, 1249-51 (1987) (giving an overview of key policy justifications for the federal securities laws in general, and anti-fraud liability in particular).

35. Low net-worth, retail investors are effectively prohibited from investing in many financial assets, including much of private equity, hedge funds, and private debt issuances, under SEC rules that limit such investments to accredited investors or qualified institutional buyers. 
investors are adequately informed before making risky investments, ${ }^{36}$ improving the allocational efficiency of capital markets, ${ }^{37}$ preventing fraud by issuers and intermediaries, ${ }^{38}$ correcting inefficiencies in the production of material investment information, ${ }^{39}$ standardizing disclosure practices among issuers, ${ }^{40}$ controlling specific managerial or promoter agency problems, ${ }^{41}$ and helping established firms create barriers to entry for new firms. ${ }^{42}$ As will be discussed in Part V, in the case of mandatory disclosure, the various goals fall within two broad categories. This whittling down still does not ease the difficulty of the task in most cases, however, as the two candidates may directly conflict with one another. ${ }^{43}$

Even if we agree on the goal and find evidence that it has been achieved, how should we weigh the benefits of this outcome against the inevitable costs associated with it? Securities regulation is not free: 44 it imposes additional costs on issuers and other market actors, and requires government expenditures on regulation and enforcement. ${ }^{45}$ Direct private costs of mandatory disclosure include the time and effort of management, and direct expenditures on underwriters, lawyers, and accountants. ${ }^{46}$ And the indirect costs of mandatory disclosure likely exceed the direct costs. For example, the sizable direct costs of mandatory disclosure may preclude small issuers from accessing the public markets for financing, thereby increasing their cost of capital and skewing investment. ${ }^{47}$ Other indirect

36. See, e.g., Stigler, supra note 24 , at 120 (analyzing mandatory disclosure).

37. Jeffrey N. Gordon \& Lewis A. Kornhauser, Efficient Markets, Costly Information, and Securities Research, 60 N.Y.U. L. REV. 761, 802 (1985).

38. See, e.g., James D. Cox, Premises for Reforming the Regulation of Securities Offerings: An Essay, 63 LAW \& CONTEMP. PROBS. 11, 12 (2000) (discussing the goals of securities regulation).

39. See generally Coffee, supra note 23.

40. See, e.g., Easterbrook \& Fischel, supra note 1, at 700-01 (naming the federal securities regulation's features).

41. See Paul G. Mahoney, Mandatory Disclosure as a Solution to Agency Problems, 62 U. CHI. L. REV. 1047,1048 (1995) (arguing that "the principal purpose of mandatory disclosure is to address certain agency problems that arise between corporate promoters and investors, and between corporate managers and shareholders"); see also Manuel A. Utset, Towards a Bargaining Theory of the Firm, 80 CORNELL L. REV. 540, 598-99 (1995) (describing managerial disclosure requirements).

42. Paul G. Mahoney, The Political Economy of the Securities Act of 1933, 30 J. LEGAL STUD. 1, 18 (2001).

43. Langevoort \& Thompson, supra note 14, at 340 (noting that securities regulation's two goals do not always coincide).

44. See Easterbrook \& Fischel, supra note 1, at 708-09 (describing indirect costs).

45. To add to the difficulty of measuring the costs of mandatory disclosure, we cannot simply add up all of the direct and indirect costs of disclosure, as this would significantly overstate the costs of regulation. Even in the absence of any mandatory disclosure requirement, issuers will expend resources to disclose some information, in order to attract investors. Id. at 682-83 (describing how firms have an interest in providing disclosure to investors). Thus, the relevant costs of mandatory disclosure to be measured are the incremental costs incurred under a mandatory disclosure regime. $I d$. at 708 (stating that the incremental costs of marginal disclosure might be small, because issuers would disclose considerable information even in the absence of disclosure). This requires a counter-factual guess as to what amount and type of information issuers would generate in the absence of mandatory disclosure. Needless to say, this is a difficult task. Id. (stating that "[w]e do not know what things firms would disclose, and to whom, in the absence of the securities laws.”).

46. Langevoort \& Thompson, supra note 14, at 367.

47. Stigler, supra note 24 , at 122 . Under a special-interest theory of regulation, this effect would be the goal of mandatory disclosure, rather than an unintended consequence. 
costs include the additional delay and uncertainty in capital raising ${ }^{48}$ the potential for liability associated with any material disclosures, ${ }^{49}$ and the forced disclosure of sensitive or proprietary company information to competitors. ${ }^{50}$

Some of these side effects may be directly antithetical to the original goals of regulation: for example, if mandatory disclosure lulls unsophisticated investors into a false sense of safety, ${ }^{51}$ or leads to less monitoring and production of information by other market actors, the securities laws may be counter-productive to the goal of helping investors make better decisions. ${ }^{52}$ The profound difficulties with identifying and measuring the costs and benefits of mandatory disclosure (and securities regulation in general) have led many to conclude, along with Donald Langevoort and Robert Thompson, that "[m]ost all of securities regulation is educated guesswork rather than rigorous cost-benefit analysis because we lack the ability to capture the full range of possible costs or benefits with anything remotely resembling precision." 53

What, then, do we know about whether mandatory disclosure is effective? In summarizing the empirical and more conceptual tests of the securities laws' effectiveness, J. Harold Mulherin ${ }^{54}$ tentatively concludes that, on balance, securities regulation has not provided demonstrable material benefits. ${ }^{55}$ Merritt Fox argues the opposite. ${ }^{56}$ Unfortunately, we appear to know very little.

48. See Cox, supra note 38 , at 17-18 (describing indirect costs of mandatory disclosure).

49. Id. at 17 .

50. See Fox, supra note 29 , at $1345-46$ (stating that private and social costs diverge). For general discussions of the costs of mandatory disclosure, see Easterbrook \& Fischel, supra note 1, at 707-14, describing costs and benefits of disclosure; see also Geoffrey A. Manne, The Hydraulic Theory of Disclosure Regulation and Other Costs of Disclosure, 58 ALA. L. REV. 473, 479-85 (2007) (reviewing literature on costs and benefits of disclosure).

51. See, e.g., Ripken, supra note 10, at 141-42 (stating that many believe the Sarbanes-Oxley reforms do nothing more than "fooling investors into a false sense of confidence").

52. This should only be the case if the market is not efficient, however, in the sense of incorporating all public information into the stock price. In an efficient market, investors should be "protected" by mandatory disclosure regardless of whether they are even aware of it. See generally Ronald J. Gilson \& Reinier Kraakman, The Mechanisms of Market Efficiency Twenty Years Later: The Hindsight Bias, 28 J. CORP. L. 715 (2003); Donald C. Langevoort, Taming the Animal Spirits of the Stock Markets: A Behavioral Approach to Securities Regulation, 97 NW. U. L. REV. 135 (2002), for summaries of the competing views and evidence on market efficiency.

53. Langevoort \& Thompson, supra note 14, at 361. For much the same reasons, the D.C. Circuit's recent insistence on full-blown cost-benefit analyses for the SEC rulemaking has been widely critiqued by the legal academy. See, e.g., John C. Coates IV, Cost-Benefit Analysis of Financial Regulation: Case Studies and Implications, (Harvard Law School European Corporate Governance Institute (ECGI), Working Paper No. 234/2014, 2014), available at $\mathrm{http}: / /$ ssrn.com/abstract=2375396 (providing case studies of regulation and their implications for cost-benefit analysis); Robert B. Ahdieh, Reanalyzing Cost-Benefit Analysis: Toward a Framework of Function(s) and Form(s), 88 N.Y.U. L. REV. 1983 (2013); James D. Cox \& Benjamin J.C. Baucom, The Emperor Has No Clothes: Confronting the D.C. Circuit's Usurpation of SEC Rulemaking Authority, 90 TEX. L. REV. 1811, 1840 (2012).

54. Mulherin, supra note 27 , at 432.

55. See also Healy \& Palepu, supra note 17, at 414 (concluding that "surprisingly little is known about why financial reporting and disclosure is regulated in the capital market").

56. Fox, supra note 29 , at 1416 (concluding that disclosure serves several socially beneficial functions). 


\section{LOANS VS. BONDS: THE TRADITIONAL PARADIGMS}

\section{A. Description of Dichotomy}

When a firm borrows money today, it can, in theory, select any point on a nearcontinuous range of more or less exotic debt instruments. But from the birth of developed capital markets in the U.S. until only a few decades ago, the choice was largely confined to one of two major paradigms: the private bank loan and the public bond. Traditional bank loans tend to occupy the highest priority in a company's capital structure: senior loans secured by all of the company's assets. ${ }^{57}$ Their terms are generally specified in loan or credit agreements containing highly restrictive covenants, which give the bank both veto rights over the borrower's major corporate transactions (such as additional debt incurrences, dividends, mergers, and major asset sales) and the ability to accelerate the loan at the first hint of financial distress. Why would a company agree to such provisions? The short answer is that, particularly for small, opaque companies, there may be no alternative to bank funding. ${ }^{58}$ Because bank loans are usually secured by the company's assets, and banks are specialized in monitoring such idiosyncratic borrowers, banks can provide these loans at relatively low interest rates. ${ }^{59}$ In exchange, they require tight controls over the borrowing firm. 60

Such bank loans thus necessarily involve long-term relationships between a given bank and a given firm: the bank invests substantial resources on due diligence and ongoing monitoring of the borrower, ${ }^{61}$ and the private information that it gleans through this process cannot readily be transferred to other parties. As described here, a bank loan is necessarily a wholly illiquid debt instrument. The originating bank will end up holding it until maturity, ${ }^{62}$ simply because no other party will value it as much as the bank does: potential third-party purchasers, lacking the bank's private information about the borrower,

57. The LoAn Syndications \& Trading Ass'N, THRough the CyClE: SEnior SeCured LOANS POISED TO PERFORM 4 (2013), available at http://www.lsta.org/hubsub.aspx?id=70.

58. See Charles K. Whitehead, The Evolution of Debt: Covenants, the Credit Market, and Corporate Governance, 34 J. CORP. L. 641, 664 (2009) (noting that less information is available about private borrowers than public ones).

59. See Douglas W. Diamond, Financial Intermediation and Delegated Monitoring, 51 REV. ECON. STUD. 393, 393 (1984) (developing a theory of financial intermediation based on minimizing the cost of monitoring borrowers).

60. See Douglas G. Baird \& Robert K. Rasmussen, Private Debt and the Missing Lever of Corporate Governance, 154 U. PA. L. REV. 1209, 1227-28 (2006) (discussing how loan covenants give lenders de facto control over the borrower); Joel Houston \& Christopher James, Bank Information Monopolies and the Mix of Private and Public Debt Claims, 51 J. FIN. 1863, 1866 (1996) (noting the significant control that lenders of private debt exert over borrowing companies).

61. Monitoring might consist of examining the borrower's collateral, testing compliance with the covenants, reviewing the company's financial statements, and meeting frequently with management.

62. See STANDARD \& POOR'S, A GUIDE TO THE LOAN MARKET 15 (2011), available at https://www.lcdcomps.com/d/pdf/LoanMarketguide.pdf ("In the old days ... . [1] oans sat on the books of banks and stayed there."). 
will discount the value of the loan accordingly. This is the essence of private debt, or relationship banking. ${ }^{63}$

At the other end of the spectrum from the small, opaque borrowers that classically relied on bank loans, we have very large, mature companies with well-understood business models and track records of providing reliable returns to their investors. Their cheapest option for large borrowings will be to issue bonds to the general public. Due to their size and established performance, retail investors are willing to purchase their bonds, notwithstanding retail investors' lack of incentives or ability to monitor the borrowing companies directly. ${ }^{64}$ Traditional public bonds are longer-term (e.g., 30-year), unsecured borrowings at fixed interest rates. As widely traded instruments underwritten by large investment banks, bonds may be highly liquid instruments, in stark contrast to the traditional bank loan. Finally, bond indentures typically contain significantly less restrictive covenants than loan agreements. ${ }^{65}$

The private bank loan and the public bond have thus long been understood as opposing paradigms of corporate debt financing. The senior secured bank loan "market" was almost by definition perfectly illiquid and monopolized by banks. The unsecured bond market was both deep and liquid, with a major retail-investor presence. Table 1 below summarizes the traditional characteristics of loans and bonds described above.

Table 1. Traditional Characteristics of Bank Loans and Public Bonds

\begin{tabular}{|l|l|l|}
\hline & Bank Loans & Public Bonds \\
\hline Lender & Single bank & Dispersed investors, including retail \\
\hline Liquidity & Very low & High \\
\hline Lender Monitoring & Intensive & Limited \\
\hline Covenants & Tight & Loose \\
\hline Credit Protection & Secured & Unsecured \\
\hline
\end{tabular}

\section{B. Treatment Under the Securities Laws}

If these traditional paradigms still held true for corporate loans and bonds, it would be difficult to find fault with their opposing treatment under the federal securities laws. Bank loans are the most commonly cited example of a non-security, while public bonds are very clearly understood to be securities, and are therefore subject to mandatory disclosure, among other requirements. ${ }^{66}$ The traditional bank loan is not viewed as requiring the

63. See, e.g., Sreedhar T. Bharath et al., Lending Relationships and Loan Contract Terms, 24 REV. FIN. STUD. 1141, 1141-42 (2011) (explaining information asymmetry's role in the development of financial intermediaries).

64. See Yakov Amihud et al., A New Governance Structure for Corporate Bonds, 51 STAN. L. REV. 447, 452-69 (1999) (examining governance structures for corporate debt).

65. Infra Part IV.B.

66. The very first paragraphs of the most widely used corporate finance textbook in business schools worldwide include the following statement: "An ordinary bank loan is not a security . . . because it is held by the bank and not sold or traded in financial markets .... The bond is a ... security, because it can be held and traded 
protections of the federal securities laws, given that: retail investors play no part in the corporate loan market; banks are themselves tightly regulated entities; credit agreements provide significant contractual protections for the lender (covenants and collateral), making them less risky - all else being equal - than bonds; and bank loans require substantial monitoring by the lender. ${ }^{67}$ Moreover, compliance with the mandatory disclosure provisions of the securities laws would usually be impossible or excessively costly for the small, opaque companies that tend to be the most common borrowers of bank loans.

In contrast, the paradigmatic public bonds are explicitly marketed to retail investors as long-term investments and may be readily traded, arguably making the ongoing availability of information about the issuer crucial. Clearly there can be no real expectation of monitoring by retail investors. Thus, the publicly issued bond has historically been viewed as demanding the mandatory disclosure apparatus.

\section{LOANS VS. BONDS: CONVERGENCE}

The contrasting paradigms of bank loans and public bonds persisted virtually untouched for decades following the Securities Acts' introduction of mandatory disclosure. But over the last 30 years (and particularly the last 15), they have been turned on their heads, primarily owing to radical changes in the bank loan market. ${ }^{68}$ The shift from traditional relationship banking to the syndication and secondary trading of loans has been both swift and sweeping. ${ }^{69}$ The gospel of the banking industry-that bank loans may not be traded - was forgotten in a matter of years. And when the smoke cleared, the business of commercial banking began to look much like the business of investment banking, and the loan market began to resemble its erstwhile opposite, the bond market. Sub-parts A and $\mathrm{B}$ below describe what brought about these changes and how they manifested.

\section{A. Causes}

\section{Changes to the Loan Market}

The seismic shifts in the corporate loan market were prompted by changes in both companies' demands for loans and creditors' supply of capital to the loan market. On the demand side, the appearance and rapid popularity of the leveraged buyout in the early 1980s significantly increased companies' appetite for taking on debt. ${ }^{70}$ It also prompted a

by many investors in financial markets." RICHARD A. BREALEY ET AL., PRINCIPLES OF CORPORATE FINANCE 2 (11th ed. 2014).

67. See Whitehead, supra note 58 , at $641-42$ (affirming banks use covenants and monitoring to minimize the risk of loss on their loans).

68. See id. at 651-52 (charting the decline in traditional banking in the last 30 years).

69. See Wilmarth, supra note 16, at 381-82 (describing the largest banks' change in business model from relationship banking to syndicated lending and securitization).

70. A leveraged buyout is a corporate acquisition in which the buyer, a "private equity" investment fund, purchases a controlling stake in the target, using only a small portion of its own funds. Steven N. Kaplan \& Per Strömberg, Leveraged Buyouts and Private Equity, 23 J. ECON. PERSP. 121, 121, 123-25 (2009). The bulk of the purchase price (typically $60-90 \%$ ) is funded by additional debt taken on by the target company at the time of the transaction. $I d$. at 124 
radical shift in companies' understanding of the role of debt in their capital structure. Debt had long been viewed as either something to avoid entirely or as a necessary evil to address the business's specific operational needs. With the advent of leveraged buyouts, however, companies began taking on debt for non-operational reasons, that is, for shareholder-driven reasons. ${ }^{71}$ With private equity in particular, debt became an end in itself: with higher leverage, private equity firms could acquire ever-larger companies (that would otherwise be immune to takeovers) and amplify returns to investors, ${ }^{72}$ while ensuring optimal incentives to ensure their investments' success. Leveraged-buyout targets thus drove a substantial increase in the demand for large corporate loans.

The supply side of the corporate loan market experienced even greater upheavals over this period. The end result was a complete reversal in the structure and composition of corporate lending, best described as the shift from an "originate-and-hold" model to an "originate-to-distribute" one. ${ }^{73}$ The initial prompt for this shift was the deregulation of the banking industry, particularly the erosion of the divide between commercial banking (taking deposits from customers and making commercial loans) and investment banking (underwriting and trading securities). Coming on the heels of the Great Depression, the Glass-Steagall Act ${ }^{74}$ aimed to make households' bank deposits more secure by prohibiting depositary banks from engaging in risky activities such as investment banking. While the goal was to keep banks out of other financial sectors, it also had the effect of shielding the banking business from competition from other financial institutions. But with the gradual paring back of Glass-Steagall and its final repeal in 1999 (with the passage of the GrammLeach-Bliley $\mathrm{Act}^{75}$ ), the neat divide between commercial and investment banking crumbled, and serious incursions were made across both sides of the aisle.

Now facing competition from insurance companies, investment banks, and mutual funds banks were forced into new lines of business to maintain profits. To add to the banks' woes, their traditional source of funds (consumer deposits) began to decline, as new alternatives for households to safely place their money arose, such as money market funds. Many banks fell by the wayside, and the industry as a whole experienced major consolidation. On the lending side, investment banks began competing with bank loans by offering companies new options for debt financing, such as issuing short-term commercial paper. ${ }^{76}$

The major triggering event for change in the traditional loan funding model was the shift in U.S. capital requirements for banks, best exemplified by the Revised Basel Capital

71. See Ulf Axelson et al., Why Are Buyouts Levered? The Financial Structure of Private Equity Funds, 64 J. FIN. 1549, 1556 (2009) (explaining the incentives that drive leveraged buyout firms to maximize the use of debt in acquisitions).

72. See Robert P. Bartlett III, Taking Finance Seriously: How Debt Financing Distorts Bidding Outcomes in Corporate Takeovers, 76 FORDHAM L. REV. 1975, 1980 (2008) (describing how debt financing is an advantage for leveraged-buyout firms over competing bidders for target companies).

73. Katerina Simons, Why Do Banks Syndicate Loans?, NEW ENG. ECON. REV. 45, 45-46 (Jan.1993), available at $\mathrm{http}: / / \mathrm{www}$. bostonfed.org/economic/neer/neer1993/neer193c.pdf.

74. The Glass-Steagall Act was the popular name for the Banking Act of 1933 , ch. 89, 48 Stat. 162 (codified as amended in scattered sections of 12 U.S.C.).

75. Financial Services Modernization Act of 1999, Pub. L. No. 106-102 (1999) (codified in scattered sections of $12,15,16,18$ U.S.C.).

76. See Whitehead, supra note 58, at $654-55$ (describing the evolution of the credit market). 
Accord ("Basel II"). ${ }^{77}$ With Basel II, bank regulators jumped with both feet onto the bandwagon of modern portfolio theory and revised bank capital requirements so as to incentivize banks to diversify their assets - until then a radical notion. Practically speaking, banks were henceforth punished for holding a small number of large loans on their balance sheets and rewarded for holding small portions of many loans. When the assets in question were securities, diversification posed little problem for banks. But with loans, the pressing question became: how could a bank hold a diversified portfolio of loans without originating all of them? Further, how could a bank transfer large loans that it had originated off its books? Recall that there was no real ability to parse and trade loans at the time. Thus, there was urgent demand for a mechanism by which portions of corporate loans could be offloaded from the originating bank to other banks and, eventually, to other types of institutions. ${ }^{78}$

This is how the practice of loan syndication and secondary trading arose and quickly became the world's largest source of corporate financing. ${ }^{79}$ With loan syndication, a major bank referred to as the lead arranger negotiates the key terms of the loan with the borrowing company, and then organizes a syndicate of lenders to fund it. ${ }^{80}$ Post-funding, if the loan is large enough it will be traded to still other investors on a secondary market. Even the lead arranger may end up holding only a small portion of the loan through this process, or sell off its stake entirely. ${ }^{81}$ Thus, syndication and secondary trading introduced several bond-like features to the loan market that were previously unimaginable: a dispersed lender base of predominantly non-bank lenders, light monitoring, and liquidity. The bank's role in this brave new world shifted from funding, monitoring, and holding the loan (an "originate-and-hold" model) to finding other investors for the loan and administering the credit relationship (an "originate-to-distribute" model). ${ }^{82}$

While banks now hold an increasingly small share of corporate loans, non-bank institutional investors have enthusiastically entered the market and rapidly surpassed banks

77. See Basel Committee on Banking Supervision, Basel II: International Convergence of Capital Measurement and Capital Standards: A Revised Framework, BANK FOR INTERNATIONAL SETTLEMENTS (June 2004), available at http://www.bis.org/publ/bcbs107.htm (establishing what it calls more "risk-sensitive" capital requirements). For a description of the impact of Basel II, see generally Robert F. Hugi et al., U.S. Adoption of Basel II and the Basel II Securitization Framework, 12 N.C. BANKING INST. 45, 48 (2008) (summarizing the final rules the U.S. federal bank regulators issued "to implement the Basel II advanced internal rating-based approach to bank capital adequacy in the United States").

78. See Yener Altunbas et al., Syndicated LoAns: A Hybrid of Relationship Lending AND PUBLICly TRADED DeBT 102 (2006) (describing how syndicated loans enable banks and other financial institutions to satisfy their capital requirements and diversify their portfolios).

79. Arthur E. Wilmarth, Jr., The Dark Side of Universal Banking: Financial Conglomerates and the Origins of the Subprime Financial Crisis, 41 CONN. L. REV. 963, 982 (2009).

80. See Allison A. Taylor \& Ruth Yang, Evolution of the Primary and Secondary Leveraged Loan Markets, in THE HANDBOOK OF LOAN SYNDICATIONS AND TRADING 21, 23-24 (Allison Taylor \& Alicia Sansone eds., 2007) (explaining the origin and growth of the syndicated loan market).

81. For descriptions of loan syndication, see Victoria Ivashina \& Zheng Sun, Institutional Demand Pressure and the Cost of Corporate Loans, 99 J. FIN. ECON. 500, 503-08 (2011); Wilmarth, supra note 79, at 981-82.

82. The latter function has proved highly lucrative for the major investment and commercial banks that dominate the lead arranger market. See Barry Bobrow et al., The Primary Market, in THE HANDBOOK OF LOAN SYNDICATIONS AND TRADING 155, 172 (Allison Taylor \& Alicia Sansone eds., 2007) (stating that the top three lead arrangers together covered $47 \%$ of the total syndicated loan market in 2005 ). 
in market share. ${ }^{83}$ In particular, securitization vehicles referred to as collateralized loan obligations (CLOs) now hold up to $60 \%$ of the market. ${ }^{84}$ Other institutional investors in the loan market include pension funds, mutual funds, hedge funds, insurance companies, finance companies, and foreign institutions. ${ }^{85}$

\section{Changes to the Bond Market}

While the bond market was less uprooted than the loan market over this period, there were nonetheless two key developments that contributed to its convergence with the loan market. First, the early 1980s witnessed the development of a high-risk segment of the market, the high-yield (or so-called "junk bond") market. Once again prompted by the leveraged-buyout appetite for large debt financing, Michael Milken at now-defunct investment bank Drexel Burnham and Lambert introduced a new debt product to the public, bonds promising very high yields and used to finance takeovers and other leveraged recapitalizations. ${ }^{86}$ Bonds were no longer the exclusive province of blue-chip, lowleverage borrowers.

Second, the direct retail investor gradually began to withdraw from the bond markets. ${ }^{87}$ Retail investors have been receding to varying degrees in all of the public markets, primarily because their participation is now funneled through intermediaries such as mutual funds and pension funds. ${ }^{88}$ Yet the phenomenon is even more pronounced in the corporate bond markets, where the direct retail investor has now all but disappeared. There are several plausible explanations for why this might be so. First, unlike the equity markets, corporate bonds are now traded almost exclusively through dealers, ${ }^{89}$ rather than on exchanges, making access difficult for direct retail investors. Second, the institutional demand for fixed-income products is so great that there is little incentive to court or even

83. Glenn Yago \& Donald McCarthy, The U.S. Leveraged Loan Market: A Primer, MILKEN INST. 26-27 (2004), available at https://www.milkeninstitute.org/pdf/loan_primer_1004.pdf (describing how prime funds, CLOs, finance companies, and insurers have replaced banks as the secondary markets' major investor).

84. Through the process of securitization, pieces of many different syndicated loans are packaged into a single vehicle, which then issues different tranches of securities to investors, thus enabling them to invest in a diversified portfolio of loans relatively cheaply.

85. Bartlett, supra note 72 , at 2013.

86. See GLENN YAGO, JUNK BONDS: How High Yield SECURITIES RESTRUCTURED CORPORATE AMERICA 20-26 (1991) (describing the history of the "junk bond revolution").

87. See James D. COX et Al., SeCurities Regulation: Cases and Materials 560 (7th ed. 2013) ("[B]ond markets are almost exclusively an institutional medium, i.e., retail investors compose a very small percentage of bond trading.").

88. See Alicia Davis Evans, A Requiem For the Retail Investor? 95 VA. L. REV. 1105, 1105 (2009) (stating that retail investors account for less than $2 \%$ of NYSE's trading volume); Donald C. Langevoort, The SEC, Retail Investors, and the Institutionalization of the Securities Markets, 95 VA. L. REV. 1025, 1026 n.4 (2009) (noting that the total value of securities that households own directly has not declined).

89. COX ET AL., supra note 87 , at 560. 
accommodate the retail investor. ${ }^{90}$ As one example, the minimum denominations for bond purchases are significantly larger than for stock. ${ }^{91}$

An astonishing feature of the various triggers for change in the loan and bond markets is that none involved a change in the treatment of either loans or bonds under the securities laws. ${ }^{92}$ The loan market went from an illiquid, bank-driven market to a full-fledged, disintermediated capital market without any loosening or tightening of the securities laws.

\section{B. Evidence}

The changes to the loan and bond markets described above have resulted in a striking and rapid convergence, particularly at the riskiest end of the spectrum in each. Both investors and issuers now view leveraged loans, which are loans to borrowers that have a high proportion of debt in their capital structure (such as private equity-owned companies), as substitutes for high-yield bonds. ${ }^{93}$ This convergence manifests most strikingly in their respective investors, pricing, liquidity, covenants, and credit features.

\section{Investors}

As discussed above, the number and type of creditors for corporate loans has changed dramatically as a direct result of the syndication and secondary trading of loans. Syndicated loans are held by large groups of dispersed creditors, consisting primarily of non-bank institutional investors having no relationship with the borrowing company. ${ }^{94}$ Given the gradual disappearance of the direct retail investor, the bond market is also now dominated by institutional investors. ${ }^{95}$ While loans and bonds began with dramatically different creditors, they now overlap very significantly, particularly in the high-yield space.

\section{Pricing}

The pricing of the loan and bond markets has converged as well, and over a very short period of time. ${ }^{96}$ Using data from the late 1980s and early 1990s, Angbazo, Mei and Saunders found that leveraged loan pricing had not yet integrated with high-yield bond

90. For regulatory or other prudential reasons, institutions such as insurance companies and pension funds have a strong preference for debt products over equity.

91. See Bessembinder \& Maxwell, supra note 4, at 221 (describing institutional investors' domination of the corporate bond market).

92. The promulgation of Rule $144 \mathrm{~A}$ did have an indirect effect on the loan market in that it opened the door for a new class of creditors, securitization vehicles such as CLOs. But the Securities Acts' regulation of loans remained unchanged.

93. See Bessembinder \& Maxwell, supra note 4, at 230.

94. In 2012, U.S. banks held only $6.3 \%$ of U.S. leveraged loans, while CLOs and loan funds together held 80.7\%. Structured Finance Industry Group, Credit Risk Retention Re-Proposal F-9 (Oct. 30, 2013), http://federalreserve.gov/SECRS/2013/December/20131219/R-1411/R1411_103013_111495_377905725574_1.pdf.

95. See COX ET AL., supra note 87 and accompanying text (describing the withdrawal of retail investors from bond markets).

96. See Wilmarth, supra note 16, at 379 (noting how banks "price and market" loans and bonds in a similar manner). 
pricing. ${ }^{97}$ Revisiting the question with more recent data, Thomas and Wang find significant integration of the leveraged loan and high-yield bond markets, with pricing in the two markets very clearly moving together. ${ }^{98}$

\section{Liquidity}

Perhaps the most striking and surprising evidence of convergence is the development of a liquid leveraged loan market, when corporate loans were for so long the consummate illiquid investment. Not all syndicated loans are traded, but large leveraged loans are specifically designed to be traded. ${ }^{99}$ Figure 1 below depicts the surge in trading volume for leveraged loans from the early 1990 s through the post-financial crisis period. While pricing in the two markets is now integrated, the leveraged loan market's trading volume has in fact recently surpassed the high-yield market's. 100

97. Lazarus A. Angbazo et al., Credit Spreads in the Market for Highly Leveraged Transaction Loans, 22 J. BANKING \& FIN. 1249, 1249 (1998).

98. Hugh Thomas \& Zhiqiang Wang, The Integration of Bank Syndicated Loan and Junk Bond Markets, 28 J. BANKING \& FIN. 229, 306 (2004).

99. There are various measures of liquidity, but one useful proxy for the liquidity of a given company's debt is simply the size (principal amount) of the loan in question. Martin S. Fridson \& Jeffrey A. Bersh, Measuring Liquidity Premiums in the High-Yield Bond Market, in THE YEARBOOK OF FIXED INCOME INVESTING 84, 89 (John D. Finnerty \& Martin S. Fridson eds., 1995). By this measure, the syndicated loan market is liquid indeed-multibillion-dollar issuances are now routine.

100. The LoAn Syndications \& Trading Ass'N, Through the CyCLE: SENIOR SECUREd LOANS POISED TO PERFORM, supra note 57 , at 14. 
Figure 1. Leveraged Loan Trading Volume 101

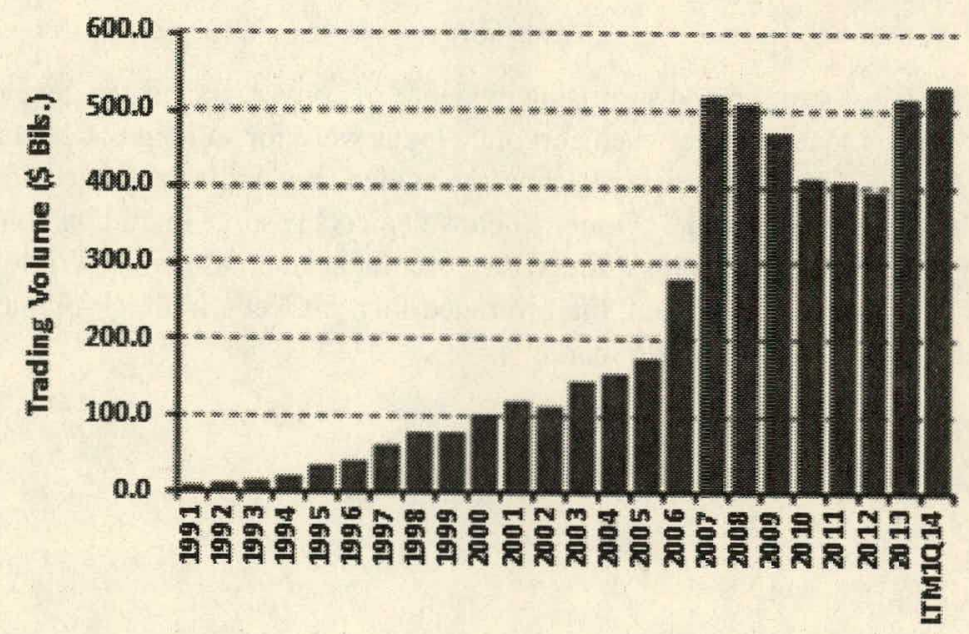

\section{Covenants}

The once-universal truth that loans come saddled with tight covenants and intensive creditor monitoring is also proving false, and syndication and secondary trading are again the culprits. While bank loans were always characterized by highly restrictive covenants, this feature could not peacefully coexist with funding by dispersed, unrelated creditors. ${ }^{102}$ Tight bank loan covenants often must be amended over the cjurse of the loan, which is easy when the loan is between a single bank and borrower. So long as the bank approves of the proposed amendment, it can be effected almost immediately. With a dispersed creditor base, however, collective action and holdout protlems among the creditors make amendments difficult, time-consuming, and often very costly. If the costs are too great, the company might be prevented from pursuing value-creating projects or pushed into bankruptcy unnecessarily. In order to avoid this problem ex ante, covenants must be less restrictive, thereby requiring fewer amendments ex post. This explains why bond covenants

101. Secondary Loan Market Volume-US, THOMSON REUTERS L?C, h.tps:/www.loanpricing.com/ (last visited Jul. 14, 2014).

102. See Wilmarth, supra note 16 , at 378 (noting that syndicated loans have fewer covenants than traditional bank loans). 
were traditionally looser than bank loan covenants, ${ }^{103}$ and why the latter have loosened dramatically since the onset of loan syndication and trading. 104

The adoption and rapid proliferation of "covenant-lite" loans is the most discussed (and criticized) manifestation of the loosening of covenants in leveraged loans. ${ }^{105} \mathrm{~A}$ covenant-lite loan does not prohibit the borrower from exceeding a specified leverage ratio, whether by taking on additional debt or simply through deteriorating performance. ${ }^{106} \mathrm{Such}$ a leverage covenant is emblematic of traditional bank loans, as it gives the lender significant control over the borrower's capital structure. In addition, it amounts to a tripwire that provides the lender with an early warning signal of potential financial distress. If a borrower violates the leverage covenant, the bank may be able to intervene in the borrower's operations early enough to stave off insolvency, or the bank can decide to accelerate and exit the loan before the situation worsens. With covenant-lite loans, as with public bonds, lenders entirely relinquish this control over the borrower.

Covenant-lite loans first appeared in and around 2005, and rapidly became popular in the leveraged loan market. Because financial covenants were a defining feature of bank loans for so long, covenant-lite loans were dismissed as a sign of lender excess in the prefinancial-crisis period that would quickly be abandoned when cooler heads prevailed. ${ }^{107}$ Yet covenant-lite loans' market share has continued to surge post-crisis, representing up to $35 \%$ of all leveraged loans outstanding in $2013 .{ }^{108}$ With the loosening of loan covenants generally, and the proliferation of covenant-lite loans in particular, leveraged loans are now

103. See Marcel Kahan \& Bruce Tuckman, Private Versus Public Lending: Evidence From Covenants, in THE YeARBOOK OF FIXED INCOME INVESTING 253, 253-74 (John D. Finnerty \& Martin S. Fridson eds., 1995) (noting one of the author's findings that "private debt covenants require more monitoring and necessitate more frequent renegotiation than public debt"); Michael Bradley \& Michael R. Roberts, The Structure and Pricing of Corporate Debt Covenants 13 (May 13, 2004) (unpublished manuscript), available at $\mathrm{http}: / / \mathrm{ssrn} . \mathrm{com} / \mathrm{abstract}=466240$ (stating that " $[\mathrm{i}] \mathrm{t}$ is clear that private debt contains far more covenants than does public debt").

104. See Whitehead, supra note 58, at 643-45 (describing the expansion of loan syndication and trading).

105. See Cem Demiroglu \& Christopher M. James, The Role of Private Equity Group Reputation in LBO Financing, 96 J. FIN. ECON. 306, 306-09 (2010) (describing the trend of declining financial covenants associated with leveraged loans).

106. See STANDARD \& POOR's, A GUIDE TO THE LOAN MARKET, supra note 62 at 18 (defining the term "covenant-lite loan").

107. You Only Give Me Your Funny Paper: Debt Markets Turn Grouchy as Creditors Ask for More, THE ECONOMIST (June 28, 2007), available at http://www.economist.com/node/9413745 (describing covenant-lite loans entered into prior to the financial crisis as a temporary trend "that in more sober times would have had lenders reaching for the Alka-Seltzer").

108. Bram Smith et al., Loan Terms \& Ways to Invest in Loans, LOAN SYNDICATIONS \& TRADING Ass'N, available at $\mathrm{http}: / / \mathrm{www} .1 \mathrm{sta}$. org/workarea/DownloadAsset.aspx?id=16747 (citing figures from Standard \& Poor's LCD). In February 2013 alone, the issuance of covenant-lite loans reached nearly fifty billion dollars in the U.S. leveraged loan market. COLM DOHERTY \& Hugo PEREIRA, THOMPSON ReUTERS LPC, LeverAGed LOAN MONTHLY: SEPTEMBER $2013 \quad 11 \quad$ (2013), available at http://share.thomsonreuters.com/loanpricing/LoanMonthly/LoanInvestorMthly_September2013.pdf 
frequently described as having "bond-style" covenants, ${ }^{109}$ and are drafted with virtually identical language and substance. 110

\section{Credit Features}

Finally, leveraged loans are converging with high-yield bonds in their most basic credit features. While traditional bank loans tended to be issued as either revolving loans or as amortizing term loans, leveraged loans are predominantly structured as nonamortizing (or minimally amortizing) term loans, similar to bonds. ${ }^{111}$ The tenor (or maturity) of leveraged loans and high-yield bonds is also now very similar, overlapping in the range of six to eight years. ${ }^{112}$

Two particularly significant differences between leveraged loan and high-yield bond facilities remain, however, both of which tend to make leveraged loans somewhat less risky, all else being equal. First, bonds still tend to provide for fixed interest, while leveraged loans generally pay out floating-rate interest, such that leveraged loan investors are not subject to interest rate risk. Second, it is still the case that leveraged loans tend to be secured by the borrower's assets, while most bonds are unsecured. ${ }^{113}$ Yet here too, change is afoot-secured bond issuances have surged in recent years. ${ }^{114}$ And on the loan front, a new product, the second-lien loan, has proven wildly popular with non-bank investors. ${ }^{115}$ While the borrower's assets secure such loans, they have second priority after the first-lien debt, and are thus highly unlikely to be fully repaid if the borrower becomes insolvent. Thus, they skirt the line between unsecured debt and secured debt very closely, and accordingly pay higher interest spreads than traditional bank debt. ${ }^{116}$ At the current state of convergence of the leveraged loan and high-yield bond markets, we are left with two products that are virtually identical from a functional standpoint. Table 2 summarizes the above by comparing the traditional loan and bond paradigms with the current highyield bond and leveraged loan markets.

109. See STANDARD \& POOR'S, A GUIDE TO THE LOAN MARKET, supra note 62 , at 18 (describing the bondlike covenants of covenant-lite loans).

110. For the seminal explanation of covenants' functions in debt agreements, see Clifford W. Smith, Jr. \& Jerold B. Warner, On Financial Contracting: An Analysis of Bond Covenants, 7 J. FIN. ECON. 117, 118-19 (1979).

111. See STANDARD \& POOR's, A GUIDE TO THE LOAN MARKET, supra note 62, at 16-17 (describing term loans).

112. See Standard \& Poor's Financial Services LLC, High Yield Bond Primer, HighyIELdBond.com, http://www.highyieldbond.com/primer/ [hereinafter Standard \& Poor's, High Yield Bond Primer] (noting that most high-yield bonds mature in seven to ten years) (last visited June 1, 2014).

113. See George G. Triantis, A Free-Cash-Flow Theory of Secured Debt and Creditor Priorities, 80 VA. L. REV. 2155, 2159 (1994) (describing the effect of secured debt on management behavior).

114. See Standard \& Poor's, High Yield Bond Primer, supra note 112 (charting the increase in the share of secured high-yield bond issuances since 2005).

115. For a description of second-lien loans, see STANDARD \& POOR's, A GUIDE TO THE LOAN MARKET, supra note 62 , at $17-18$.

116. See StANDARD \& POOR's, A GUIDE TO THE LOAN MARKET, supra note 62, at 17 (noting that the interest-rate spread between second-lien and first-lien loans typically ranges from 200 to 1000 basis points). Another oft-noted difference between loans and bonds is that bond indentures are, in principle, enforced by a trustee on behalf of the noteholders. In practice, however, bond trustees do not engage in any independent monitoring of borrowers, and serve merely to administer the credit relationship and coordinate noteholder actions. See Steven L. Schwarcz \& Gregory M. Sergi, Bond Defaults and the Dilemma of the Indenture Trustee, 59 ALA. L. REV. 1037, 1044 (2008) (highlighting the largely ministerial role of bond trustees). 
Table 2. Leveraged Loan and High-Yield Bond Convergence

\begin{tabular}{|l|l|l|l|}
\hline Lender & $\begin{array}{l}\text { Traditional } \\
\text { Bank Loans }\end{array}$ & $\begin{array}{l}\text { Traditional } \\
\text { Public Bonds }\end{array}$ & $\begin{array}{l}\text { Leveraged Loans and High- } \\
\text { Yield Bonds }\end{array}$ \\
\hline Liquidity & Very low & $\begin{array}{l}\text { Dispersed } \\
\text { investors, including } \\
\text { retail }\end{array}$ & $\begin{array}{l}\text { Dispersed investors; } \\
\text { institutional only (and mostly } \\
\text { non-bank) }\end{array}$ \\
\hline $\begin{array}{l}\text { Lender } \\
\text { Monitoring }\end{array}$ & Intensive & Limited & High \\
\hline Covenants & Tight & Loose & Limited \\
\hline $\begin{array}{l}\text { Credit } \\
\text { Protection }\end{array}$ & Secured & Unsecured & $\begin{array}{l}\text { Leveraged loans: } \\
\text { predominantly secured, with } \\
\text { second-lien loans increasing } \\
\text { High-Yield bonds: } \\
\text { predominantly unsecured, but } \\
\text { secured bonds increasing in } \\
\text { market share }\end{array}$ \\
\hline
\end{tabular}

\section{Are Syndicated Loans Securities?}

Notwithstanding their functional convergence with public bonds, corporate loans that are syndicated and traded continue to be treated as non-securities under U.S. law, thereby avoiding all disclosure requirements thereunder. In the public bond market, mandatory disclosure in practice means that the initial bond issuance must be offered to the public by means of a detailed registration statement that frequently runs in the hundreds of pages. Post-funding, the issuer may still be subject to ongoing disclosure requirements, even if it is a private company, so long as the bonds have at least 300 holders of record. ${ }^{117}$ Finally, the issuance is subject to various antifraud provisions of the Securities Acts including most significantly Rule 10b-5. ${ }^{118}$ The loan market avoids these entirely. Instead, leveraged loans tend to be marketed to investors with slim "bank books" containing a short term-sheet for the credit facility and management projections. ${ }^{119}$ The only additional disclosure requirements to which the borrower is subject are contractual ones - the covenants for which lenders negotiate in the credit agreement. ${ }^{120}$ But in light of the rise of syndicated

117. 15 U.S.C. $\$ 78 \mathrm{o}(\mathrm{d})(2012)$.

118. 17 C.F.R. $\$ 240.10$ b-5 (2013).

119. See STANDARD \& POOR's, A GUIDE TO THE LOAN MARKET, supra note 62, at 9 (describing a bank book's typical content).

120. Unlike shareholders, creditors are not owed fiduciary duties by directors or officers, unless the company becomes insolvent. See N. Am. Catholic Educ. Programming Found. Inc. v. Gheewalla, 930 A.2d 92, 101-03 (Del. 2007) ("[T]he creditors of an insolvent corporation have standing to maintain derivative claims against directors ... ." (emphasis in the original)); Geyer v. Ingersoll Publ'ns, 621 A.2d 784, 787-88 (Del. Ch. 1992) (" $[\mathrm{T}]$ he general rule is that directors do not owe creditors duties beyond the relevant contractual terms absent 
lending and secondary trading of loans, is the regulatory distinction between loans and bonds defensible under the law?

\section{The Reves Framework}

The Securities Act's remarkably expansive definition of a "security" includes any "note, ... bond, debenture, evidence of indebtedness, . . . investment contract, . . . or any certificate of interest or participation in ... any of the foregoing." 121 The Securities Acts do not treat all promissory notes or debt instruments as securities, however. The foregoing definition's laundry-list of instruments is subject to the equally expansive caveat "unless the context otherwise requires," leaving to the courts the task of determining the definition's actual contours. ${ }^{122}$

The judicial analysis of whether a particular debt instrument is a security proceeds in what is by now a well-established order. In Reves v. Ernst \& Young, ${ }^{123}$ the Supreme Court adopted the Second Circuit's "family resemblance" test, which begins with a presumption that every note is a security, in light of the all-encompassing Securities Act definition. ${ }^{124}$ This presumption may be rebutted, however, if the note strongly resembles one of the families of instruments previously determined by the courts to be non-securities, all according to the following four factors:

(1) "[T]he motivations that would prompt a reasonable seller and buyer to enter into" the transaction;

(2) "[T]he 'plan of distribution' of the instrument[;]"

(3) "[T]he reasonable expectations of the investing public[;]" and

(4) "[W]hether some factor such as the existence of another regulatory scheme significantly reduces the risk of the instrument, thereby rendering application of the Securities Acts unnecessary." 125

If the note in question does not sufficiently resemble one of the families of nonsecurities, the court must determine whether to create a new category of non-security, employing the same four-factor analysis. ${ }^{126}$ The note is deemed a security if it fails both tests. In addition to clarifying the analysis for debt instruments, the Reves Court reiterated the long-held view that traditional bank loans should not be subject to securities regulation,

special circumstances ... e.g., fraud, insolvency, or a violation of a statute ....") (internal quotes omitted); Credit Lyonnais Bank Nederland, N.V. v. Pathe Commc'ns Corp., Civ. A. No. 12150, 1991 WL 277613, at*1155-57 (Del. Ch. Dec. 30, 1991) (holding that when facing insolvency, a board does not breach its fiduciary duties by placing the corporate enterprise interests before shareholders).

121. 15 U.S.C. $\$ 77 b(a)(1)$ (2012) (providing the Securities Act of 1933 's definition of a "security"). Note, however, that the definition of a "security" under the Securities Exchange Act of 1934 does not include the words "evidence of indebtedness." 15 U.S.C. § 78c(a)(10) (2012).

122. 15 U.S.C. $\S \S 77 \mathrm{~b}(\mathrm{a}), 78 \mathrm{c}(\mathrm{a})(2012)$.

123. Reves v. Ernst \& Young, 494 U.S. 56, 63 (1990), reh'g denied, 494 U.S. 1092 (1990).

124. Id. at 63,65 .

125. Id. at $66-67$.

126. Id. at 67. 
noting that "notes evidencing loans by commercial banks for current operations" are among the categories of non-securities. ${ }^{127}$

\section{Banco Espanol}

The question of whether syndicated loans in their current incarnation are securities has not yet come before the courts. The case that is thought to be authoritative on this question, Banco Espanol de Credito v. Security Pacific National Bank, ${ }^{128}$ deals with their precursor-loan participations. ${ }^{129}$ Syndicated loans are traded on the secondary market by assignment, which transfers all of the rights and duties of the assignor lender to a new lender. In contrast to a loan assignment, a loan participation is merely a promise by an existing lender to distribute its share (or a portion of its share) of all principal and interest payments on the loan to a third party. ${ }^{130}$

At issue in Banco Espanol was a loan participation program in which Security Pacific, a nationally chartered bank, solicited various investors to purchase participations in unsecured, short-term loans that it had originated to a financial service company, Integrated Resources, Inc. When Integrated began defaulting on its loans, the purchasers of the loan participations, having no recourse against the borrower, ${ }^{131}$ sued Security Pacific for failing to disclose material facts about Integrated's financial condition as required by Section 12(2) of the Securities Act. ${ }^{132}$ The success of such a claim depended on a finding that the participations were, in fact, securities.

The first question the court tackled was how to treat the loan participation in relation to the loan itself for purposes of the securities laws. Here, the court noted with approval the district court's conclusion that, while "a participation in an instrument might in some

127. Id. at 65 (quoting Chemical Bank v. Arthur Andersen \& Co., 726 F.2d 930, 939 (2d Cir. 1984), cert. denied, 469 U.S. 884 (1984)).

128. Banco Espanol de Credito v. Sec. Pac. Nat'1 Bank, 973 F.2d 51 (2d Cir. 1992), cert. denied, 509 U.S. 903 (1993).

129. Id. at 53. Loan participations became popular before the current practice of fully transferring loans by assignment. See Robert F. Kornegay, Jr., Bank Loans as Securities: A Legal and Financial Economic Analysis of the Treatment of Marketable Bank Assets under the Securities Acts, 40 UCLA L. REV. 799, 825 (1993) (charting the rise of loan participations).

130. See Richard Wight et AL., THe LTSA's Complete CREDit Agreement Guide 507, 507-08 (2009) (discussing the difference between assignments and participations). Loan participations were a convenient way of transferring the risk of loans off banks' balance sheets without requiring them to actually assign the loans. The lender effectively acts as a pass-through, sending proceeds from the loan received from the borrower directly to the purchaser of the loan participation. Because the loan participant is not in contractual privity with the borrower, it generally has no voting rights under the loan agreement, no direct recourse to the borrower's assets in the event of default, and no other traditional lender powers. Id. Most importantly from the perspective of the securities laws, perhaps, is the fact that the purchaser of the loan participation receives only the information that the lender contracts to share with it, which may be less than what the borrower is required to provide to the lender under the loan agreement. Id.

131. See id. (stating that the holder of a loan participation is not in contractual privity with the borrowing company).

132. Banco Espanol de Credito v. SEC Pac., Nat'l Bank, 763 F. Supp. 36, 38 (S.D.N.Y. 1991); see also '33 Act, 15 U.S.C. $\S 771$ (2014). 
circumstances be considered a security even where the instrument itself is not[,]"133 in this case the loan participation "did not have an identity separate from the underlying loan."134 This conclusion alone is puzzling, given that the loan agreement was a contract between the borrower, Integrated, and the original lender, Security Pacific, while the participation was solely between Security Pacific and the purchasers, and had wholly different terms. ${ }^{135}$ Specifically, the purchasers did not have the lenders' rights under the loan agreement, and in particular did not have access to information about the borrower that other lenders did. 136

In a relatively cursory opinion, a majority of the Second Circuit affirmed the district court's judgment that the loan participations were not securities for purposes of the Securities Acts, concluding that the loan participations bore a "family resemblance" to loans by commercial banks to their customers for current operations, a well recognized category of non-securities. ${ }^{137}$ Specifically, the court agreed with the district court's conclusions under the four-factor Reves test that: first, the parties' primary motivation was commercial; second, the plan of distribution did not resemble that of securities because "only institutional and corporate entities were solicited" and resales were prohibited without Security Pacific's consent; third, the investing public would reasonably have perceived that these were participations in loans rather than investments; and fourth, another regulatory scheme mitigated the need for securities regulation, because the Office of the Comptroller of the Currency ("OCC") had issued policy guidelines for the sale of loan participations. ${ }^{138}$

In a strong dissent, the Chief Judge agreed with the SEC's amicus brief that the loan participations were securities because they differed from traditional loan participations in at least four key respects: (1) the nature and number of the purchasers, (2) the purchasers' purpose, (3) the marketing of the loan participations, and (4) the information made

133. Banco Espanol, 973 F.2d at 54 (citing Banco Espanol de Credito v. Sec. Pac. Nat'l Bank, 763 F. Supp. 36, 41 (S.D.N.Y. 1991)).

134. Id. (citing Banco Espanol, 763 F. Supp. 36, 42 (S.D.N.Y. 1991)).

135. Banco Espanol de Credito v. Sec. Pac. Nat'1 Bank, 763 F. Supp. 36, 37-38 (S.D.N.Y. 1991).

136. Id. at 38 .

137. Banco Espanol, 973 F.2d at 55-56.

138. Id. at 54. Surprisingly, the court did not address whether the loan participations were securities in the form of "investment contracts," the analysis for which is set forth in SEC v. W.J. Howey Co., 328 U.S. 293 (1946). Pre-Reves cases had rejected arguments that loan participations or syndications were "investment contracts," on the theory that interest on a loan is not the type of "profit" associated with an investment purpose. See McVay v. W. Plains Serv. Corp., 823 F.2d 1395, 1400 (10th Cir. 1987) (holding that a participant in a loan agreement held no interest in loan funds, the note, or mortgages other than "bare legal title"). But in SEC v. Edwards, 540 U.S. 389 (2004), the Supreme Court cast doubt on the continued validity of these cases, by holding that for purposes of the investment contract test, "profits" does not require something akin to an equity interest; a fixed interest (such as interest on a loan) may suffice. See Edwards, 540 U.S. at 897-99 (holding that contract yielding a fixed rate of return can be a security). The Reves test was intended to supplant more free-form analyses such as the Howey test for "investment contracts" in the specific case of debt instruments. See Reves, 494 U.S. at 64 (rejecting other courts' application of the Howey test to notes). Yet the Howey lineage of cases strongly informed Reves, and is still thought to constitute an additional test that a debt instrument must fail before it can be conclusively ruled a non-security. In fact, Fox v. Dream Trust, 743 F. Supp. 2d 389, 398 (2d Cir. 2010) states that certain loan participations may potentially constitute notes that are securities and investment contracts. See Fox, 743 F. Supp. $2 \mathrm{~d}$ at 398 (finding that the participation agreement at issue was a security and an investment contract). 
available to the purchasers. ${ }^{139}$ First, although some banks purchased the loan participations, there were also many "non-financial entities" seeking to make an investment. ${ }^{140}$ Second, a sales desk at Security Pacific within its trading department (rather than its commercial loan department) ran the loan participation program. ${ }^{141}$ Third, promotional materials portrayed the loan participations as competitive with commercial paper (which is undeniably a security), referred to the purchasers as "investors," and emphasized the ability to trade the loan notes. ${ }^{142}$ Finally, the purchasers did not receive any nonpublic information about the borrowers at issue, thereby sharply distinguishing them from commercial lenders and placing them in a significantly less well-informed position than the original lender, Security Pacific. ${ }^{143}$

The majority opinion is indeed misleading in describing the loan participation program as a small number of private, fully negotiated arrangements between Security Pacific and a select group of purchasers regarding a specific commercial loan. Security Pacific's loan notes program was far broader than the loan participations at issue in this case: it covered 100-250 borrowers and involved 600-700 investors at the time. ${ }^{144}$ Moreover, purchasers did not approach Security Pacific with respect to Integrated's loan specifically; rather, the trading desk at Security Pacific would solicit investors through daily calls (some of which were "cold calls") regarding any number of different loans. ${ }^{145}$

If the majority opinion holds on even these facts, the ruling is broad indeed and exempts a large swath of trading programs related to instruments formally designated as loans. While subsequent cases have interpreted Banco Espanol narrowly, ${ }^{146}$ it has not been overturned and is widely considered to apply to both loan participations and syndicated loan assignments. ${ }^{147}$ Yet, the court decided Banco Espanol in 1992, at a time when the syndicated loan market was on the cusp of its rapid expansion, and had not reached anywhere near its current level of depth and liquidity. While there is a strong case to be made that Banco Espanol was wrongly decided at the time, we are still left with the question of whether it is good law in light of the interim changes to the loan market. In particular, how do syndicated loans fare today under a Reves analysis?

139. Banco Espanol, 973 F.2d at 56 (Oakes, C.J., dissenting).

140. Id.

141. Id. at 57 .

142. Id. at 58 .

143. Id.

144. Banco Espanol, 973 F.2d at 58 (Oakes, C.J., dissenting).

145. Id. at 57 .

146. See Pollack v. Laidlaw Holdings, Inc., 27 F.3d 808, 815 (2d Cir. 1994) (holding, on a limited set of facts, that passive investors in a participation agreement were protected by federal securities laws). Decided only a year after Banco Espanol, the Second Circuit's Pollack decision concluded that unsecured mortgage participations marketed to passive individual investors were securities under the Securities Acts. Id. Oddly, the court did not overturn Banco Espanol, despite upending its key underpinnings. Infra Part IV.C.3.

147. See generally Syndicated Loans as Securities, PROSKAUER ROSE LLP (2011), available at http://www.proskauer.com/files/uploads/broker-dealer/Syndicated-Loans-as-Securities.pdf (discussing the framework for determining whether syndicated loans are securities and including a discussion of Banco Espanol). 


\section{Reves Applied to Syndicated Loans}

We begin by applying the four Reves factors to syndicated loans. ${ }^{148}$

The first Reves factor looks to whether the parties' motivations were investment (which would weigh in favor of treatment as a security) versus commercial or consumer (which would weigh in favor of treatment as a non-security). ${ }^{149}$ The Banco Espanol majority made much of the fact that Security Pacific was primarily in the business of making commercial loans, but only a year later, the court acknowledged that the primary focus should be on the motivation of the purchaser of the instrument. ${ }^{150}$ Specifically, a buyer's investment motivation trumps a seller's commercial motivation. ${ }^{151}$

Purchasers in the leveraged loan market regularly describe themselves as investors, rather than as lenders. ${ }^{152}$ Aside from the lead arranger, members of the syndicate generally have no relationship or even contact with the borrower, and they do not view their efforts or input as affecting the borrower's success. ${ }^{153}$ In the leveraged loan space, their expectation is clearly to be able to trade their loan holdings on a liquid market. ${ }^{154}$ All of these bespeak an investment, rather than commercial, objective. Turning to the borrower, in a leveraged loan transaction, the borrowing company is rarely seeking funds for current operations. Instead, banks fill such needs via revolving lines of credit. ${ }^{155}$ Leveraged loans are typically used for shareholder-specific reasons (such as to issue dividends to shareholders) or to make new investments (such as acquisitions). ${ }^{156}$ Finally, although lead

148. As a preliminary matter, it is worth distinguishing broadly between two types of syndicated loans: the revolving loan and the term loan. Revolving loans are borrowings under a line of credit that is kept open for the company for a defined period, and which may be borrowed, repaid, and re-borrowed up to the credit limit at any time. See STANDARD \& POOR's, A GUIDE TO THE LOAN MARKET, supra note 62, at 16. Such lines of credit are typically used for short-term operational needs. Id. at 7. Term loans, in contrast, are typically multi-year loans that are borrowed entirely upfront only once and repaid only at maturity. Id. at 16 (noting that term loans generally involve a series of repayments or a single lump sum repayment). Syndicated revolving loans continue to be funded exclusively by banks, which have the capacity to keep such lines of credit open at very low interest rates, and are significantly less risky than term loans. $I d$. at 10 (noting that banks generally provide unfunded revolving credits). Thus, though they are syndicated, revolving loans still resemble the archetypal bank loan in many respects, thus arguing for their treatment as non-securities. In contrast, syndicated term loans have experienced the most dramatic change, as they are now funded primarily by non-banks and involve greater levels of risk and less monitoring and creditor protection. See supra Part IV.B (describing changes to the syndicated loan market). Thus, for the remainder of this discussion, "syndicated loans" will refer exclusively to syndicated term loans, for which the treatment as non-securities is the weakest.

149. Reves v. Ernst \& Young, 494 U.S. 56, 63-65 (1990) (discussing the "investment v. commercial" test and noting its similarity to the "family resemblance" test which was adopted).

150. Pollack v. Laidlaw Holdings, Inc., 27 F.3d 808, 812-13 (2d Cir. 1994) (holding that the buyer appellant's motivation to invest indicated the note was a security despite the sellers motivation).

151. Id.

152. See STANDARD \& POOR's, A GUIDE TO THE LOAN MARKET, supra note 62 , at 10 (describing the various participants in the "loan investor market").

153. See Simons, supra note 73 , at 46 (describing the lead arranger as an intermediary between the borrower and the rest of the syndicate).

154. See STANDARD \& POOR's, A GUIDE TO THE LOAN MARKET, supra note 62, at 15 (describing the role played by liquidity in loan pricing).

155. See supra note 148 .

156. See Fox v. Dream Trust, 743 F. Supp. 2d 389, 399 (2010) (noting that these features point towards an investment motivation). 
arranger positions continue to be filled by large investment or commercial banks, their role in such capacity is not to fund companies' operations. Lead arrangers are in the business of collecting fees for performing what is effectively an underwriting function, and should therefore not be viewed as lenders. ${ }^{157}$

The second Reves factor, the plan of distribution, considers the manner in which a debt instrument is marketed and sold, and to whom. Whereas traditional bank loans are private, bilateral, long-term agreements between a single company and its relationship bank, syndicated loans are distributed much like public securities. First, the number of creditors can be very large, whether at the initial syndication or through subsequent trading and securitization. Second, they are marketed widely by the lead arranger's syndication desk, rather than the commercial lending desk. ${ }^{158}$ The loan's origination is thus divorced from the loan's distribution. The purchasers of leveraged loans are primarily non-banksthat is, institutions unable to closely monitor borrowers and with very different objectives. ${ }^{159}$ CLOs, the primary purchasers of leveraged loans, exist solely to hold investments. ${ }^{160}$ All of these weigh heavily in favor of treatment as securities.

Only two features leveraged loan distribution differ from a classic public distribution of securities. First, although trading in the leveraged loan market is heavy (and in fact heavier than for high-yield bonds), it is still the case that the borrower's consent is typically required for any assignment of the loan. ${ }^{161}$ However, credit agreements for leveraged loans routinely provide that the borrower may not unreasonably withhold consent, and if the borrower fails to respond to a request for consent within a specified number of days, it is deemed to have acquiesced to the assignment. ${ }^{162}$ Second, leveraged loans are marketed only to institutional investors, and never to direct retail investors. ${ }^{163}$ Yet the Reves Court confirmed that offerings to sophisticated parties may nonetheless amount to public distribution. ${ }^{164}$ Indeed, direct retail investors are absent from the high-yield bond market as well, and high-yield bonds very clearly continue to be regulated as securities.

Under the third Reves factor, an instrument may be characterized as a security notwithstanding its underlying economics if the "reasonable perception of the instrument by the investing public" is that of an investment. ${ }^{165}$ Because leveraged loans are explicitly marketed as investments, the purchasers of such loans describe themselves as investors, and they are risky commitments of capital for at least several years, it would be difficult to

157. Victoria Ivashina \& Anna Kovner, The Private Equity Advantage: Leveraged Buyout Firms and Relationship Banking, 24 REV. FIN. STUD. 2462, 2464 (2011) (noting the appeal of fee income for lead arrangers).

158. See Wilmarth, supra note 16, at 379 ("The growing importance of institutional investors has caused lead banks to price and market their syndicated loans in a manner similar to corporate bonds.").

159. See Yago \& McCarthy, supra note 83, at 26-27 (discussing how initially banks dominated the secondary market for syndicated loans but as the market developed, nonbanks are now the main participants).

160. See Richard W. Stewart, Collateralized Loan Obligations: A Primer, in THE HANDBOOK OF LOAN SYNDICATIONS AND TRADING 646, 646-47 (Allison Taylor \& Alicia Sansone eds., 2007) (describing a CLO as "a special-purposes investment vehicle (SPV) established to accumulate a diversified pool of loans").

161. See WigHT ET AL., supra note 130 (outlining lender consent rights).

162. Id.

163. See Fox v. Dream Trust, 743 F. Supp. 2d 389, 398 (2010) (noting that distribution of a note to retail investors weighs in favor of its treatment as a security).

164. Reves v. Ernst \& Young, 494 U.S. 56, 68 (1990).

165. Banco Espanol de Credito v. Sec. Pac. Nat'l Bank, 973 F.2d 51, 55 (2d Cir. 1992). 
characterize them as anything other than investments. On the other hand, it is also clear that, as institutional investors, loan purchasers should be well aware that loans are not currently regulated as securities. This Reves factor's framing thus suffers from a circularity problem. Should the fact that investors are aware that leveraged loans are treated as nonsecurities imply that they can never be regulated as securities? That result seems implausible.

The fourth Reves factor considers whether the debt instrument contains or is subject to some risk-reducing factor. Riskier financial instruments are, generally speaking, more likely to call for the protection of the securities laws, and thus risk-reducing features weigh against treatment as a security under Reves. The Banco Espanol court relied on the OCC's oversight of national banks to find this fourth factor satisfied with respect to loan participations. The court's conclusion on this factor is puzzling, given that many of the purchasers of the loan participations were non-banks. ${ }^{166}$ Moreover, for purposes of the fourth Reves factor, it is not sufficient simply to point to the existence of another regulatory scheme; such regulation must in some way reduce the risk of the instrument for the purchaser. ${ }^{167}$

The fact that most leveraged loans are secured by the assets of the borrowing company is thus a more plausible risk-reducing factor than the OCC's bank oversight. ${ }^{168}$ Yet secured bonds, which are increasingly common, remain securities, notwithstanding the existence of collateral protection. Conversely, many leveraged loans are unsecured or second-lien, and thus far neither the courts nor the SEC have treated such instruments as securities.

Thus, each of the four Reves factors weighs in favor of treating syndicated loans as securities. This is particularly so for leveraged loans. The Reves analysis suggests that leveraged loans, which are widely traded, highly risky investments, fit very poorly within the commercial loan framework that has until now justified their treatment as nonsecurities. 169

More generally, the Reves analysis of leveraged loans uncovers a key flaw in the family resemblance test: gauging whether a debt instrument is analogous to a particular

166. For a critique of the Banco Espanol court's reliance on the OCC regulatory scheme, see Louisa C. Crampton, Originating Lender Bank Liability to Participants in the B-Tranche of a Leveraged Loan: Mending the Gap Between Federal Banking and Federal Securities Regulation, 1 N.C. BANKING INST. 255, 283-86 (1997), stating that while the Banco Espanol court considered the OCC's Banking Circular 181 to be "an adequate substitute for the federal securities laws" it did not further examine the guidelines "to ensure that they would provide participants with protections against nondisclosure, fraud, or misrepresentation by the originating bank"; Kornegay, supra note 129, at 848 (arguing that the relevant OCC guidelines did not protect investors in loan participations).

167. See Richard Y. Roberts \& Randall W. Quinn, Leveling the Playing Field: The Need for Investor Protection for Bank Sales of Loan Participations, 63 FORDHAM L. REV. 2115, 2117 (1995) (asserting that "purchasers of loan participations that function as investments should be protected by the federal securities laws").

168. See Fox, 743 F. Supp. 2d at 400 (citing Bass v. Janney Montgomery Scott, Inc., 210 F.3d 577, 585 (6th Cir. 2000)) (explaining that the fourth Reves factor "calls for examination of other risk-reducing factors, such as collateralization").

169. As discussed, that loans are regulated differently from securities stems from their history as bilateral, illiquid commercial arrangements. In this regard, the odd regulatory status quo of syndicated loans is similar to that of derivatives, which historically were not regulated as securities simply due to their origins in the commodities realm. See Roberta Romano, The Political Dynamics of Derivative Securities Regulation, 14 YALE J. ON REG. 279 (1997). 
family of instruments deemed non-securities becomes a meaningless exercise when the underlying archetypes for each family are themselves rapidly changing. Indeed, the Banco Espanol court sought to determine whether the loan participations at issue were analogous to commercial loans, yet failed to acknowledge that the paradigm of commercial lending was itself in flux. ${ }^{170}$

\section{Regulatory Stickiness}

If leveraged loans and high-yield bonds are now virtually interchangeable, and if a correct application of the case law would conclude that leveraged loans are securities, where are the calls to treat them accordingly? Treating like cases alike is a fundamental principle of the legal system in a liberal democracy, ${ }^{171}$ regardless of whether it is achieved or even achievable in practice. More mundanely, the persistence of the regulatory distinction between leveraged loans and high-yield bonds now borders on the absurd. Why then are the major regulatory and market players silent on this issue?

One likely explanation is that the SEC has bigger fish to fry. After the Second Circuit dealt it a loss in Banco Espanol, the SEC apparently decided to take a wait-and-see approach with respect to syndicated loans. And in the meantime, the securities markets were rocked by successive large-scale scandals such as Enron, the executive compensation and earnings management accounting scandals of the early $2000 \mathrm{~s}$, the dot-com bubble bursting, the Madoff Ponzi scheme, and the mortgage-backed securities and credit default swap implosions. By contrast, the leveraged loan market has hummed along relatively smoothly. ${ }^{172}$ Though issuance volume and trading surged over the last decade-an obvious trigger for regulatory attention - the leveraged loan market has yet to experience the major upheavals or scandals that would force the SEC's hand by drawing the public's attention. The leveraged loan market is at once the most dynamic and the least visible capital market in the U.S., which is exactly how its participants like it.

Of course, the financial crisis hardly left the syndicated loan market unscathed. The largest U.S. banks had committed to funding billions in leveraged loans just before the credit crisis began, and were unable to offload the commitments, triggering massive and immediate losses on their balance sheets. ${ }^{173}$ Yet the credit crunch in the leveraged loan market failed to trigger the public ire for two reasons.

First, the significantly larger losses from mortgage-backed securities and credit default swaps made these better targets for a Wall Street backlash than syndicated lending. Second, unlike the subprime mortgage blowup, which affected seemingly everyone from the largest financial institutions down to the American consumer, the leveraged loan crisis was relatively well contained to the financial players involved in purchasing leveraged

170. For a different critique of Reves in this context, see Crampton, supra note 166, at $271 \mathrm{n} .122$ and accompanying text, explaining that the Reves court "acknowledged this lack of predictability".

171. See, e.g., RONALD DWORKIN, TAKING RightS SERIOUSLY 227 (1977) (identifying the right to equal treatment, which is defined as "the right to an equal distribution of some opportunity or resource or burden").

172. See Amar Gande \& Anthony Saunders, Are Banks Still Special When There Is a Secondary Market for Loans?, 67 J. FIN. 1649, 1650 (2012) (noting that the trading volume for syndicated loans declined only slightly during the recent financial crisis, as compared to the crashes in structured finance).

173. Wilmarth, supra note 79 , at 971. 
loans. When the crisis hit, commentators immediately predicted a rash of bankruptcies by over-leveraged companies, particularly private equity-owned ones, which, it was said, had pushed the envelope of easy credit too far. But as of 2014 we are still waiting for the other shoe to drop. While below-investment grade issuers did experience increased defaults postcrisis, the effects did not nearly trickle down to corporate America and consumers to the extent predicted. ${ }^{174}$

Moreover, to the extent that observers were concerned by over-lending in the leveraged loan market, the blame was placed on the folly of investors, rather than on issuers' fraudulent behavior. There were no real allegations that leveraged issuers had misstated their financials or otherwise misled creditors or provided insufficient disclosure; high-yield investors simply made a bad bet. Imposing new disclosure requirements on issuers of leveraged loans would thus have been an odd solution. ${ }^{175}$ Finally, and perhaps most significantly for purposes of this Article, to the extent that the leveraged loan market suffered harm, the high-yield bond market suffered even more. ${ }^{176}$ It would be difficult to point to securities regulation as the solution to problems in the leveraged loan market when an equivalent regulated market experienced the very same problems.

A second possibility is that the SEC is incentivized to remain hands-off with respect to private markets (such as the corporate loan markets), even as they expand and thrive, while tightly regulating the already-existing public markets. ${ }^{177}$ Zachary Gubler argues that the SEC has strong incentives not to regulate private capital markets, notwithstanding their dramatic expansion and relatively anemic activity in the public markets (particularly the market for IPOs). ${ }^{178}$ This is so, he argues, because the SEC employees' private incentives are not best served by forever expanding the SEC's regulatory reach. Rather, the SEC employees may be better off allowing vast, unregulated private markets to develop, in order

174. First, the defaults were very frequently resolved as voluntary workouts among creditors (particularly when the borrower was private-equity-owned), avoiding the upheavals of bankruptcy and the finality of liquidation. See Ernst \& Young, Private Equity Buys Time with Major Refinancings, KNOWLEDGE@WHARTON at 4 (Apr. 24, 2012), https://knowledge.wharton.upenn.edu/article/ernst-young-private-equity-buys-time-withmajor-refinancings/. Second, many leveraged issuers took advantage of a temporary credit easing in the highyield bond market in late 2010 to refinance their leveraged loans as high-yield bonds (pointing once again to the fluidity between, and interchangeable nature of, the two markets) and extend the maturities on their debt. Id. As a result, the American public did not experience the trauma of a major wave of corporate bankruptcies resulting from pressure in the leveraged loan market.

175. See John C. Coffee, Jr., Gatekeeper Failure and Reform: The Challenge of Fashioning Relevant Reforms, 84 B.U. L. REV. 301, 329 (2004) (noting that during periods of irrational investor behavior such as market bubbles, investors tend to ignore or discount correct information that would dampen their exuberance). In recent years, the key regulatory concern in the corporate loan and bond markets has not been issuers abusing investors, but systemic effects from overly permissive lending by depositary banks or other large financial institutions. I suspect that there is broad agreement that this problem is best addressed by regulating lending institutions themselves (for example, through strict minimum capital requirements for banks), rather than through new regulation of all assets in which lending institutions might possibly invest.

176. See Sansone et al., supra note 15, at 4 (noting a higher default rate for high-yield bonds than for leveraged loans on average).

177. See generally Zachary J. Gubler, Public Choice Theory and the Private Securities Market, 91 N.C. L. REV. 745 (2013).

178. See id. (discussing the smaller number of interest groups affected in the private markets compared to public markets). 
to keep special interest groups happy and maximize their future job opportunities. Simultaneously, to reassure the general public that they are acting diligently, they will impose tight regulation in the markets that are already public. If correct, Gubler's hypothesis would explain the observed pattern of regulatory laissez-faire with respect to leveraged loans.

A final intriguing explanation for the continued discrepancy in the regulation of loans and bonds is the one proffered in Part V of this Article, namely that the relevant actors all recognize that, in practice, applying securities regulation simply would not make much of a difference. At base, the current situation is one in which the regulatory treatment is determined simply by whether the borrower and investors choose to refer to the instrument as a "loan" or a "bond." In effect, loan market participants are making the fact of nonregulation a self-fulfilling prophecy by deliberately keeping their eyes shut to the absurdity of this dichotomy. ${ }^{179}$ They are gambling that the courts and regulators will not upset current practice with trillions of dollars at stake. ${ }^{180}$

Putting aside the regulatory inertia, in an ideal world, what ought to be done about the specious distinction between leveraged loans and high-yield bonds? An obvious solution is to begin regulating leveraged loans as securities, and subject them to the same mandatory disclosure and other securities rules as high-yield bonds. This, I have argued, would be the doctrinally correct answer. Yet, the next Part demonstrates that mandatory disclosure is ineffective in the high-yield bond market, making it inadvisable as a policy choice.

\section{THE DEBT-MARKET NATURAL EXPERIMENT}

\section{A. Natural Experiment}

Part II of this Article detailed the difficulties involved in testing whether mandatory disclosure is effective. While we are unlikely ever to answer the question of whether securities regulation is effective generally-for all times and all market actors - we may still draw lessons from developments in the financial markets and continued testing. One option is to watch opportunistically for special market conditions that approach the randomized trial ideal. The convergence of the leveraged loan market and the high-yield bond market presents precisely such a situation: for the first time, we have a pair of virtually identical debt markets - with the same issuers, investors, pricing, and terms - and only one of which is regulated as a securities market.

Much can be salvaged from this natural experiment, notwithstanding the obstacles to a true empirical test. The trick is to return to the goals of mandatory disclosure in securities regulation. If we take the SEC at its word that it acts in the public interest, and thereby rule out special-interest goals, we find that the various public-interest goals of mandatory

179. The definitive reference on the development and mechanics of syndicated loans begins with the following admonition: "LOANS ARE NOT SECURITIES!" Allison Taylor \& Alicia Sansone, Preface to THE HANDBOOK OF LOAN SYNDICATIONS AND TRADING xv, xvi (Allison Taylor \& Alicia Sansone eds., 2007). The emphasis strongly suggests that this statement is not merely descriptive, but precatory.

180. Cf. Langevoort \& Thompson, supra note 14 , at 385 (describing generally how market participants rapidly exploit regulatory voids, notwithstanding the legal risks, because doing so gives them significantly greater political and estoppel grounds to resist an unfavorable regulatory change). 
disclosure noted in Part II.B fall into two broad categories: (1) protecting unsophisticated investors, and (2) correcting inefficiencies in the production, dissemination, and verification of investment information. 181

To clarify the second goal, securities-law scholars generally agree that in the absence of mandatory disclosure, it is at least conceivable that the amount of credible, material information available to investors would be suboptimal. ${ }^{182}$ Why might financial markets, left to their own devices, generate too little credible information or distribute it inefficiently? Although material information about issuers is clearly valuable to investors, they may not be willing to pay for such information to be produced and verified: due to the difficulties of coordinating as a group and the ability to free-ride on others' efforts, they will underinvest in information. ${ }^{183}$ Conversely, by duplicating some of each other's efforts in the absence of public disclosure, investors and analysts may simultaneously overinvest in information. ${ }^{184}$ Imposing disclosure requirements on issuers could mitigate these inefficiencies in the market for investment information. Through detailed requirements as to the content, timing, and format of corporate disclosures, backed up by robust antifraud liability, mandatory disclosure could correct both the underproduction of accurate investment information and the overproduction of false or misleading investment information that would occur in an unregulated market. ${ }^{185}$

This hypothesis has testable implications. If investors are rational, they will reward markets subject to mandatory disclosure with more investment. ${ }^{186}$ So long as it is not excessively costly, the imposition of mandatory disclosure should result in an increase in a given market's amount of investment. By effectively subsidizing the production and dissemination of reliable information, and punishing the production of false or misleading information, mandatory disclosure should push the amount of investment closer to the optimal equilibrium.

181. See, e.g., Joel Seligman, The Historical Need for a Mandatory Corporate Disclosure System, 9 J. CORP. L. 1, 9 (1983) (discussing five principal arguments to justify the SEC's mandatory corporate disclosure system); Langevoort \& Thompson, supra note 14, at 372.

182. Explanations for why issuers might produce less information than is socially optimal center on freeriding and collective action problems among investors and analysts, as well as the third-party externalities associated with disclosure. See, e.g., Coffee, supra note 23, at 731-34 (arguing that mandatory investment can prevent over and under-investment in securities research by analysts); Easterbrook \& Fischel, supra note 1, at 686 (acknowledging that firms might under-disclose in the absence of regulation because disclosure by one firm benefits investors in other firms, as well as non-shareholder constituencies); Zohar Goshen \& Gideon Parchomovsky, The Essential Role of Securities Regulation, 55 DUKE L.J. 711, 755-66 (2006) (arguing in favor of mandatory disclosure as reducing information traders' search costs, and therefore increasing market efficiency). The basis for all of these arguments is the notion that information is a public good. Fox, supra note 29, at 1393-95; Dale Arthur Oesterle, The Inexorable March Toward a Continuous Disclosure Requirement for Publicly Traded Corporations: “Are We There Yet?" 20 CARDOZO L. REV. 135, 198-201 (1998).

183. See supra note 182 (detailing the various explanations for why investors might underinvest in information).

184. See Coffee, supra note 23, at 731-34 (arguing that mandatory investment can prevent both over and under-investment in securities research by analysts).

185. See generally supra note 10 (discussing that one the goals of mandatory disclosure is to remedy the underproduction of material investment information).

186. See Easterbrook \& Fischel, supra note 1, at 673 ("A world with fraud, or without adequate truthful information, is a world with too little investment ...."). 
In testing this hypothesis, we face the problem that the first goal of mandatory disclosure, protecting unsophisticated investors, may have precisely the opposite effect on investment. For example, regulatory efforts to prevent unsophisticated investors from taking on too much risk might take the form of actively discouraging or even prohibiting them from investing, resulting in less investment overall in that particular market. Yet, in the corporate debt markets our task is immensely simplified, as direct retail investors are effectively absent from both the leveraged loan and high-yield bond markets. ${ }^{187}$ The first goal of mandatory disclosure can be safely ignored, clearing away much of the complexity on both the benefit and cost sides of the regulatory equation. With retail investors out of the picture, we are left with only the second goal: remedying inefficiencies that suppress the production of accurate investment information by issuers. This allows us to employ the level of investment in a given market as a rough proxy for the effectiveness of securities regulation: mandatory disclosure should drive up investment in that market; its absence should spur a decline in investment.

Assume for the time being that the leveraged loan and high-yield bond markets are perfectly identical as a functional matter, save for their regulation. ${ }^{188}$ If mandatory disclosure were truly achieving its goal in the high-yield bond market, then investors (and therefore issuers) should prefer it to the leveraged loan market. Stated differently, if mandatory disclosure is indeed effective at solving investors' free-riding and collective action problems, it should be in the joint best interests of investors and issuers to subject firms to it. Investors and issuers should flock to the regulated market and shun the unregulated market, such that we would observe all of the volume and liquidity in the highyield bond market.

Yet, instead the leveraged loan market has flourished and now exhibits greater volume and liquidity than its regulated counterpart. ${ }^{189}$ Under the orthodoxy of mandatory disclosure, a liquid leveraged loan market ought not to exist. This fact alone therefore poses a significant problem for the current regulatory regime: it is not achieving its only plausible goal.

\section{B. How We Got Here and What to Do About It}

Unfortunately, our work is not yet done. The conclusion that mandatory disclosure is ineffective does not on its own reveal the right policy response because we are left with a puzzle: how is it that the leveraged loan and high-yield bond markets continue to exist sideby-side? Under our simple thought experiment above, if mandatory disclosure were effective, there would be no leveraged loan market. Yet, if mandatory disclosure is indeed ineffective, as I have argued, there should be no high-yield bond market.

We therefore have a puzzle in two parts. First, just why is it that mandatory disclosure might be proving ineffective? How can we explain the dizzying growth of the leveraged loan market in the absence of securities regulation? Why would investors ever favor an equivalent market to high-yield bonds providing less disclosure? Second, if mandatory disclosure is indeed ineffective, how can we explain the continued existence of the high-

187. See Evans, supra note 88 , at 1105 (stating that retail investors owned less than $30 \%$ of U.S. corporations' stock in 2009).

188. This assumption will be relaxed in Part V.B.2 infra.

189. See supra note 13 (stating that the leveraged loan market reached $\$ 664$ million in issuances in 2012). 
yield bond market? Why wouldn't issuers and investors avoid the costs of ineffective regulation in the high-yield market and deal exclusively in leveraged loans? Only by answering these questions can we determine the appropriate regulatory course of action.

\section{Why the Leveraged Loan Market?}

If mandatory disclosure is indeed ineffective in the debt markets, and leveraged loans have thrived accordingly, there would seem to be two plausible explanations. One possibility is that the information failures that may originally have justified its imposition no longer exist or have been sufficiently mitigated through non-regulatory mechanisms. Indeed, how could there be a liquid leveraged loan market in the absence of mandated disclosure? What has prompted non-bank investors to purchase loans so willingly, despite declining covenant protection and monitoring? Why were loans entirely illiquid just over 30 years ago-precisely due to the difficulty of transferring information about the issuer to another creditor - when today they are heavily traded?

It must be that loan investors are relying on new sources of information or mechanisms for disseminating it, obtained solely through private ordering. As discussed in Part IV.A, deregulation of the banking industry and capital requirements favoring diversification prompted strong demand for tradable loans. And once the demand was there, institutional structures quickly arose to satisfy it, including by getting material information out to investors. The Loan Syndications and Trading Association, a private trade association for lenders, was created and prompted a slew of changes making possible the widespread syndication and secondary trading of loans. ${ }^{190}$ These included drafting standardized loan assignment forms (similar in function to the International Swaps and Derivatives Association forms for derivatives) and credit agreement provisions, facilitating mark-to-market pricing, and creating a pricing index for loans. All of these either conveyed previously unavailable information about loan issuers to investors or facilitated the rapid dissemination of existing information. ${ }^{191}$

As the market developed, the credit rating agencies began rating syndicated loans, ${ }^{192}$ Committee on Uniform Securities Identification Procedures (CUSIPs) were added to credit facilities, the financial press began covering leveraged loans, and specialized databases began compiling loan pricing and terms that were formerly entirely private. ${ }^{193}$ It turns out that dispersed lenders can obtain valuable information about borrowers and credit facilities from a wide range of sources, even when the borrower is a private company. ${ }^{194}$ While the

190. See Allison A. Taylor, The LSTA and its Role in the Promotion of the Corporate Loan Asset Class, in THE HANDBOOK OF LOAN SYNDICATIONS AND TRADING 61, 61-75 (Allison Taylor \& Alicia Sansone eds., 2007) (discussing the Loan Syndications and Trading Association's history, an overview of its significant accomplishments, and analysis of its impact on the development of that asset class during the 1990s and 2000s).

191. Even in imperfectly efficient markets, prices incorporate all manner of investment-relevant information. See Whitehead, supra note 58, at 667-70 (describing how the pricing of private debt may convey private information held by banks to other investors).

192. STANDARD \& POOR'S, A GUIDE TO THE LOAN MARKET, supra note 62, at 11.

193. The continued standardization of U.S. accounting principles has also undoubtedly favored lenders, as lenders can delegate monitoring to audit firms by requiring borrowers to have their financials audited.

194. The success of the loan market is particularly surprising in light of the fact that there is no true exchange or other single private institution that oversees or directs disclosure and other practices in the markets. The Loan 
credit rating agencies' failures are legion, ${ }^{195}$ the rating agencies clearly perform better when rating traditional corporate debt instruments (such as loans and bonds) than complex mortgage-backed securities and the related structured asset products for which they were notorious during the financial crisis. ${ }^{196}$ Through their (albeit imperfect) gatekeeping function, the credit rating agencies convey to the wider loan investor community substantial private information obtained during their ratings process.

Finally, it may be that the lead arranger ${ }^{197}$ of a leveraged loan financing acts as a "reputational intermediary" 198 between issuers and loan investors. When a lead arranger retains some portion of a loan on its books, rather than syndicating the entire loan, it certifies to some degree the issuer's creditworthiness to the rest of the syndicate. ${ }^{199}$ If so, the lead arranger mitigates to some degree the relative dearth of publicly available information. Through any or all of these mechanisms, private ordering in the leveraged loan market appears to be substituting for the types of information that the securities laws require issuers to disclose publicly.

A different possibility for why mandatory disclosure is proving ineffective and the leveraged loan market has prospered is that, while information production may indeed be suboptimal in unregulated debt markets, mandatory disclosure is a poor solution to the problem. Because we have no ready means of determining what optimal disclosure might

Syndications and Trading Association (LSTA), the trade association for loan market participants, performs many useful coordinating functions in the loan market, but does not impose mandatory terms or disclosure. See Taylor, supra note 190, at 61 (describing the LSTA as "promot[ing] cooperation and coordination between the firms transacting in loans" through a "consensus-building process"). This is in contrast to the public securities markets, in which private institutions such as the securities exchanges exercise a quasi-regulatory function. See Paul G. Mahoney, The Exchange As Regulator, 83 VA. L. REV. 1453, 1457-58 (1997) (describing incentives for private institutions to regulate the securities market). Many vocal critics of regulatory overreach in the securities markets argue that the exchanges already provide adequate oversight: in other words, we need not fear deregulation if there is an alternative institution that can coordinate and direct the market. Id. at 1459.

195. See, e.g., John Patrick Hunt, Credit Rating Agencies and the "Worldwide Credit Crisis": The Limits of Reputation, the Insufficiency of Reform, and a Proposal for Improvement, 2009 COLUM. BUS. L. REV. 109, 113 (2009) (noting the inherent conflicts of interest involved in the ratings process, given that the rating agencies are paid by the issuers being rated); Frank Partnoy, The Siskel and Ebert of Financial Markets?: Two Thumbs Down for the Credit Rating Agencies, 77 WASH. U. L. Q. 619, 648-49 (1999) (noting the lack of competition among rating agencies); Frank Partnoy, How and Why Credit Rating Agencies Are Not Like Other Gatekeepers, in FinANCIAL GATEKeEPERS: CAN THEy PROTECT INVESTORs? 59, 64 (Yasuyuki Fuchita \& Robert E. Litan eds., 2006) (arguing that rating agencies are encouraged even by investors to provide overly optimistic ratings).

196. See Elisabeth de Fontenay, Private Equity Firms as Gatekeepers, 33 REV. BANKING \& FIN. L. 115, 177-78 (2013) (explaining why the credit rating agencies performed especially poorly in rating structured asset products during the financial crisis).

197. See Taylor \& Yang, supra note 80 and accompanying text (explaining the function of lead arrangers of syndicated loans).

198. Gilson \& Kraakman, supra note 29, at 618.

199. See generally Amir Sufi, Information Asymmetry and Financing Arrangements: Evidence from Syndicated Loans, 62 J. FIN. 629 (2007) (finding that lead arrangers retain larger shares of loans on their books through the syndication process when the borrowing company requires more intense screening and monitoring). To date, the evidence on whether lead arrangers themselves perform a gatekeeping role is mixed, as there is some evidence that bank monitoring declines with loan syndication and secondary trading, but that investors are willing to buy simply because of the benefits of diversification. Gande \& Saunders, supra note 172, at 1675-77. For an overview of the literature summarizing the competing views on whether lead arrangers perform a risk-reduction function in the syndicated loan markets, see ALTUNBAS ET AL., supra note 78, at 75-78 (2006). 
be, the current mandated disclosure may simply be excessive or cover the wrong information. ${ }^{200}$ Similarly, while the SEC is sophisticated and relatively well-staffed, the regulatory process is undeniably slow. ${ }^{201}$ To the extent that the optimal type and amount of disclosure changes over time, the securities regulations may be slow to respond, at least relative to practices in the private markets. By effectively prohibiting innovation in disclosure, the regulated markets may be straying ever further from optimal disclosure than the unregulated markets.

A final explanation for the leveraged loan phenomenon should be mentioned - and dismissed. The natural experiment described in Part A is imperfect because the issuers may choose whether to issue loans or bonds, and therefore whether to subject themselves to securities regulation. ${ }^{202}$ This introduces the possibility of selection bias, which departs from the drug-trial ideal of randomization. To the extent one observes different outcomes in these markets, these may be due to unobserved ex ante differences in their respective issuers, for example, rather than purely due to the application vel non of securities regulation. Given that issuers view the two forms of debt as substitutes ${ }^{203}$ and that many issuers have both leveraged loans and high-yield bonds in their capital structure at the same time, ${ }^{204}$ there are unlikely to be significant ex ante differences between issuers in the two groups. But these cannot be ruled out with theory alone. What we can rule out is the possibility that the leveraged loan market is simply the market for "lemons," 205 to which low-quality issuers run to escape the securities registration process. The relative credit risks of the leveraged loan and high-yield bonds markets belie any such adverse selection effect: while leveraged loans and high-yield bonds have similar historic default rates $(4 \%$ and $4.3 \%$, respectively), the average creditor recovery following a default is significantly higher for leveraged loans (66\%) than for high-yield bonds (41\%). ${ }^{206}$

200. In addition to imposing direct, out-of-pocket costs on issuers (and therefore investors), excessive disclosure also imposes indirect costs on investors. See supra notes 44-50 and accompanying text (discussing the cost of mandatory disclosure). For example, if issuers disclose everything under the sun, investors could be more inclined to lose the forest for the trees, to become inured to disclosure (c.f., the ubiquitous "Risk Factors"), or worse, it might enable issuers to and hide bad information in a sea of innocuous information (the proverbial needle in a haystack).

201. See Mulherin, supra note 27 , at 424 (discussing the difficulties posed by the lengthy regulatory process for empirical tests of regulation).

202. See, e.g., Joshua Rosenbaum \& Joshua Pearl, InVestment Banking: Valuation, LeVeraged BUYOUTS, AND MERGERS AND ACQUISITIONS 178 (2009) (noting that targets of leveraged buyouts may be funded by bank loans, high-yield bonds, or some combination of the foregoing, among other types of debt).

203. See supra note 16 and accompanying text (discussing syndicated loans and bonds as substitutes).

204. See Robert P. Bartlett III, Going Private but Staying Public: Reexamining the Effect of Sarbanes-Oxley on Firms' Going-private Decisions, 76 U. CHI. L. REV. 7, 22-23 (2009) (discussing the issuance of leveraged loans and high-yield bonds).

205. George A. Akerlof, The Market for "Lemons": Quality Uncertainty and the Market Mechanism, 84 Q.J. ECON. 488, 495 (1970).

206. The Loan Syndications \& Trading Ass'N, Through the CyCle: SEnior SECUREd LoAns Poised TO PERFORM, supra note 57, at 9. See also Sansone et al., supra note 15 and accompanying text (discussing the peak of leveraged loans and high-yield bonds). 


\section{Why the High-Yield Bond Market?}

If this Article's thesis regarding the ineffectiveness of mandatory disclosure is correct, the continued existence of the high-yield bond market demands explanation. Why would companies still choose to issue in the public high-yield bond market, given the added regulatory transaction costs? Here the possibilities are three-fold.

First, it may be that for some subset of particularly risky or opaque firms, the choice of the high-yield market (and thus of mandatory disclosure) may serve as a credible signal of quality, without which such firms would not be able to attract investors. If so, then mandatory disclosure is doing some work for a small segment of the overall market, and this Article's conclusion about the failings of mandatory disclosure should be scaled back accordingly.

The second possibility, for which there is considerably more support, is that many of the largest institutional investors in the U.S. financial markets such as pension funds, mutual funds, and insurance companies are required to hold all or some minimum portion of their assets in the form of registered securities. These requirements may take the form of either regulatory fiat ${ }^{207}$ or internal policies adopted for prudential reasons. Both reflect the long-standing (though increasingly contestable) notion that, all else being equal, registered securities are safer than unregistered ones. Such investors cannot hold a portfolio comprised exclusively of leveraged loans. Thus, to reach such investors, some subset of all borrowing companies will issue publicly registered high-yield bonds, rather than loans.

A third possible raison d'être for the high-yield bond market stems from the fact that, notwithstanding our prior assumption, the convergence of the leveraged loan and highyield bond markets is as yet incomplete. While the two instruments can be rendered functionally identical in any given instance through drafting, in practice we still find certain differences between them on average, though these are rapidly diminishing. ${ }^{208}$ Most significantly, it is still the case that leveraged loans tend to be secured by the borrowing company's assets, which reduces credit risk, while high-yield bonds tend to be unsecured. ${ }^{209}$

This dichotomy points the way to what ought to be the ongoing natural experiment in this area. We begin by categorizing leveraged loans and high-yield bonds according to whether they are secured by the borrower's assets. Table 3 below provides the current state of each such market segment.

207. See, e.g., VANGUARD Group, InC., PART B VANGUARD FIXED Income SECURITIES FundS StATEMENT OF ADDITIONAL INFORMATION B-26 (2013), available at https://personal.vanguard.com/pub/Pdf/sai028.pdf (describing the SEC regulations limiting mutual funds' holdings of illiquid and restricted securities, which include unregistered securities).

208. See supra Part IV.B (discussing the remaining differences between leveraged loans and high-yield bonds).

209. See RosenBaum \& PEARL, supra note 202, at 184-85 (describing high-yield bonds as "typically unsecured"). 
Table 3. High-Yield Fixed Income-Current State

\begin{tabular}{|l|l|l|}
\hline & Leveraged Loans & High-Yield Bonds \\
\hline Secured & Large volume & Small, but increasing volume \\
\hline Unsecured & $\begin{array}{l}\text { Small, but increasing volume; } \\
\text { recent surge in second-lien loans }\end{array}$ & Large volume \\
\hline
\end{tabular}

The focus of the experiment should be on two market segments: (1) unsecured leveraged loans, and (2) secured bonds. It would strongly signal that mandatory disclosure is proving unnecessary for investors in the corporate debt markets if unsecured leveraged loans continued to expand and eventually rivaled the size of the unsecured bond market. For this reason, regulators should keep an especially close eye on the volume of secondlien loans, which are tantalizingly close to unsecured debt. ${ }^{210}$ If the second-lien market continues its rapid expansion, it would suggest a surprising shift in loan investors' expectations - away from negotiated credit protection (covenants, monitoring, and collateral) ${ }^{211}$ and toward alternative sources of risk reduction, ${ }^{212}$ all in the absence of mandatory disclosure. On the other hand, if the secured bond market continues to expand, notwithstanding the ready alternative of secured loans, we would have to acknowledge that, whether it is effective or not, securities regulation in the fixed-income markets is not proving particularly burdensome.

\section{Implications}

Whether the explanation is that information is now cheaply and reliably produced in the debt markets without regulatory intervention, or that mandatory disclosure only makes information problems worse, the conclusion that mandatory disclosure case is ineffective is a troubling one. There would seem to be a strong case not only for continuing to rely solely on private ordering in the loan markets, but also for jettisoning mandatory disclosure in the bond markets. Yet, I remain agnostic about whether scaling back the securities regulation of bonds is the appropriate response. In fact, there are several plausible justifications for maintaining the regulatory status quo, notwithstanding the doctrinal inconsistency.

First, maintaining the two markets side-by-side may yield invaluable information as to what optimal disclosure actually looks like. To the extent that disclosure in the leveraged loan market continues to diverge from that in the high-yield bond market, even while the leveraged loan market continues to thrive, mandated disclosure may well be too ossified to be useful for investors. ${ }^{213}$ If disclosure in the two markets begins to converge, however,

210. STANDARD \& POOR's A GUIDE TO THE LOAN MARKET, supra note 62, at 17-18 (describing secondlien loans and noting their higher yields and looser covenants as compared to first-lien debt).

211. See Whitehead, supra note 58, at 643-44 (finding that monitoring and covenants may no longer be the most cost-efficient means of managing credit risk).

212. See supra Part V.B.1 (providing explanations for the leveraged loan phenomenon).

213. Langevoort \& Thompson, supra note 14, at 365 (recognizing that it is an open question whether the SEC is imposing the optimal level of disclosure). 
we can be more confident that the SEC is adequately anticipating investors' needs. This would provide useful guidance for other markets subject to mandatory disclosure such as the public stock markets. Second, certain institutional investors are still confined to holding registered securities, such as public bonds. ${ }^{214}$ Eliminating mandatory disclosure in the high-yield bond market would preclude such investors from participating in the market going forward.

Note that as we approach true interchangeability of loans and bonds, we also approach a regime in which securities regulation is truly elective. Such a regime has heretofore only been envisioned, and sometimes advocated, by scholars. ${ }^{215}$ While private markets of tradable non-securities have existed for some time (think of over-the-counter derivatives contracts), we have never before had a situation in which a non-securities market was essentially identical to a public securities market in pricing, terms, investors, and liquidity. Allowing this natural experiment to persist should yield crucial insights not only into the debt markets, but also into securities regulation in general.

\section{Final Caveats}

The conclusion that mandatory disclosure is ineffective in the debt markets, though significant, should be appropriately cabined. In particular, it is unclear whether it can be extended to the equity markets. Many of the differences between debt and equity, and in particular between debt investors and equity investors, bear on the wisdom of mandatory disclosure.

First, and most importantly, the private ordering that exists in the debt markets to generate information and reduce risk may not be feasible in the equity markets. The pillars of mandatory disclosure - the disclosure of financial information and anti-fraud liability are voluntarily adopted in loan agreements. Through routine covenants, borrowers agree to produce periodic financial statements throughout the life of the loan, and have them audited and distributed to creditors. ${ }^{216}$ Similarly, borrowers make a standard representation in loan agreements that specifically tracks the language of Rule 10b-5.217 Thus, by means of contract, loan investors negotiate for similar protections to what the securities laws mandate.

Why are such private ordering solutions infeasible for stockholders? The key difference is that corporate debt is outstanding for a limited and predetermined period of time, most often less than ten years. The relevant parties can agree relatively easily on what would be useful for investors to know and what would be feasible for the company to provide while the loan is outstanding. Equity, on the other hand, is of potentially infinite

214. See supra note 207 and accompanying text (discussing the SEC's regulations limiting mutual funds' holdings).

215. See, e.g., Romano, supra note 29, at 2361-62 (advocating a reconceptualization of securities regulation to a market approach, "by modifying the federal law in favor or a menu approach to securities regulation under which firms elect whether to be covered by federal laws or by the securities law of a specified state"); Stephen J. Choi \& Andrew T. Guzman, Portable Reciprocity: Rethinking the International Reach of Securities Regulation, 71 S. CAL. L. REV. 903, $904-06$ (1998) (recommending a "regulatory regime that focuses on regulatory competition and gives issuers and investors the ability to choose the law that governs their transactions").

216. WIGHT ET AL., supra note 130.

217. Id. at 273 . 
duration. The transaction costs would be too high for the company and its stockholders to agree ex ante on what the company would provide as disclosure forever, and amendments would be too costly. 218

A second difference may be linked to the stage in the corporate lifecycle at which mandatory disclosure comes into play. Equity funding of some kind is clearly required from the outset, while debt financing is usually only available when the firm has reached a certain level of maturity and stability in its cash flows. The fact that debt is most typically issued by mature companies lessens both the riskiness of the investment and the difficulty of specifying appropriate disclosure. ${ }^{219}$

Third, although their participation is declining as a percentage of the whole, direct retail investors still hold a meaningful share of the public equity markets. ${ }^{220}$ As discussed, the protection of investors that have little ability to bear losses is a fundamentally different, and sometimes conflicting, goal from correcting the market's informational inefficiencies. ${ }^{221}$ The foregoing analysis of mandatory disclosure only holds to the extent that we put aside the goal of protecting unsophisticated investors, which we can comfortably do in the corporate debt markets. 222

\section{E. The $144 A$ Red Herring}

As a result of the 1990 promulgation of Rule $144 \mathrm{~A}$, the regulatory divide between loans and bonds is in fact more nuanced than it has been depicted here thus far. ${ }^{223}$ Rule

218. See generally OLIVER HART, Firms, CONTRACTS, AND FinANCIAL STRUCTURE (1995) (using the theory of incomplete contracts to justify firms' capital structure); Robert E. Scott \& George G. Triantis, Incomplete Contracts and the Theory of Contract Design, 56 CASE W. RES. L. REV. 187 (2005). This is partly why corporate charters and by-laws are so spare in their provisions - they are intended to govern indefinitely. Another way of saying this: we can say with something like a straight face that debt issuances involve a negotiated contractual relationship between issuers and investors, whereas the notion becomes more dubious for equity, the terms of which generally amount to a take-it-or-leave-it proposition.

219. Cf. Andrew A. Schwartz, The Perpetual Corporation, 80 GEO. WASH. L. REV. 764, 787 (2012). With equity investments, the nightmare (and not implausible) scenario for regulators is that shareholders will lose their entire investment. With debt, that concern is significantly lessened-debt instruments (at least, straight debt instruments) are simply less risky on average, because they are higher in priority in the capital structure than equity.

220. As but one example, the SEC's exemption for private placements under Rule 506 and congressional preemption of state regulation have arguably opened the door to significant abuses in small placements, involving the marketing of highly risky and sometimes fraudulent securities to unwary individuals with little ability to bear losses. See Jennifer J. Johnson, Private Placements: A Regulatory Black Hole, 35 DEL. J. CORP. L. 151, 188 (2010) (stating that exemption makes retail investors vulnerable).

221. For this reason, if we opted to scale back securities regulation of the bond markets, the void may need to be filled by restrictions on individuals' direct participation in the market. In other words, this might push us into a system of regulating investors rather than issuers. See Stephen Choi, Regulating Investors Not Issuers: A Market-Based Proposal, 88 CAL. L. REV. 280, 283 (2000) (advocating for a regime in which the nature of the investor determines securities regulation).

222. If this Article's conclusion does not necessarily extend to equity, the same is true as to other, more exotic types of debt and more complex financial instruments such as derivatives, which have less well-established markets and market participants, and raise a host of different concerns, including a greater likelihood of systemic effects if the market sours. With derivatives in particular, losses can be amplified far beyond the "mere" loss of one's investment, making systemic effects more likely than for traditional corporate debt.

223. 17 C.F.R. $\S 230.144$ A (2013). 
144A exempts from securities registration any resales of securities made exclusively to qualified institutional buyers (QIBs), that is, to financial institutions that own and manage more than $\$ 100$ million in investments. ${ }^{224}$ Sales of corporate bonds under Rule 144A have been wildly popular, including in particular in the high-yield space. A typical high-yield bond offering of this type begins with the sale of the bonds from the issuer to the underwriters (referred to in this context as "initial purchasers"). ${ }^{225}$ Rule 144A then exempts from registration under the ' 33 Act the resale of the notes from the underwriters to the ultimate investors, and all subsequent trading among investors, so long as they are QIBs. Thus, unregistered Rule 144A notes occupy a place on the spectrum between traditional, private bank loans and public, registered bonds. Furthermore, like syndicated loans, they blur the distinction between private and public debt.

Because Rule 144A high-yield offerings are not subject to mandatory disclosure under the securities laws, at first blush they appear to be an obvious starting point for testing the effects of mandatory disclosure in the debt markets: the natural experiment would simply involve comparing registered (public) high-yield bonds to unregistered (Rule 144A) highyield bonds, rather than to leveraged loans. And in fact, the disclosure provided in offering memoranda for Rule 144A offerings is virtually identical to that in registration statements for public bonds, notwithstanding the absence of disclosure requirements. ${ }^{226}$ Does this imply that mandated disclosure in the public market is in fact the optimal level of disclosure? ${ }^{227}$ If private offerings voluntarily mimic disclosure in the public markets, shouldn't that suggest that the public markets require the "right" level of disclosure?

Unfortunately, the disclosure practices in the Rule 144A market are a false lead. Voluntary disclosure under Rule 144A mimics disclosure for registered offerings because Rule $144 \mathrm{~A}$ merely serves as a waiting room ${ }^{228}$ for public registration. Bonds that are initially sold under Rule 144A are most often subsequently exchanged into registered public bonds. ${ }^{229}$ The offering memorandum for a Rule 144A offering anticipates that event and its disclosure is prepared accordingly. ${ }^{230}$ Why the two-step registration process? Rule $144 \mathrm{~A}$ allows issuers to close deals quickly and avoid the delay associated with registered

224. 17 C.F.R. $\S 230.144$ A(a)(1)(i) (2013).

225. MARK B. TRESNOWSKI \& Gerald T. NOWAK, THE High YIELD OFFERING: AN ISSUER's PERSPECTIVE 49 (2004), available at http://www.kirkland.com/files/Nowak_HighYieldOfferingsBook.PDF. The sale of securities to the underwriters is exempt from registration as a private placement under Section 4(2) of the ' 33 Act. Id.

226. Id. at 25 (describing the offering memorandum for a Rule $144 \mathrm{~A}$ offering as looking "very much like the prospectus for a registered public offering").

227. See, e.g., Bartlett, supra note 204, at 20 (2009) (describing the Sarbanes-Oxley's effect on firms' goingprivate decisions).

228. Credit is due to Don Langevoort for suggesting this analogy.

229. See William J. Whelan III, The Statutory Arrangement for Public and Private Securities Offerings under the Securities Act of 1933, in SECURITIES OfFERINGs 2007: OPERATING UNDER THE NEW RULES 49,59 (Practicing Law Institute 2007) (discussing how "many offerings under Rule 144A are convertible debt" where "the issuer typically agrees to file a so-called resale shelf-registration statement in order to provide investors with freely tradable securities"); TRESNOWSKI \& NOWAK, supra note 225, at 25 (describing the offering memorandum's resemblance to a registration statement for a public offering); ROSENBAUM \& PEARL, supra note 202, at 185 (stating that, typically, high-yield bonds are initially sold to QIBs under Rule 144A, and then registered with the SEC within one year).

230. TRESNOWSKI \& NOWAK, supra note 225 , at 51. 
offerings, ${ }^{231}$ while the eventual registration eliminates the Rule $144 \mathrm{~A}$ resale restrictions and brings in investors who are restricted to holding registered securities. ${ }^{232}$ Thus, while the dramatic growth of the $144 \mathrm{~A}$ market is fascinating in its own right, its disclosure practices unfortunately do not help us understand whether the disclosure mandated for public bond offerings is optimal.

\section{CONCLUSION}

The answer to whether mandatory disclosure, the lynchpin of federal securities regulation, is effective has long remained elusive. Thanks to a novel natural experiment, however, we may finally have that answer for the largest source of corporate financing, the corporate debt markets. If leveraged loans, which continue to be treated as non-securities, can surpass high-yield bonds in depth and liquidity, mandatory disclosure is not the optimal mechanism for investment information that it purports to be. Solely through private ordering, the loan market is now generating sufficient information to entice more robust investment and trading than its regulated counterpart. What this means for securities regulation is less clear. Though the continued regulatory discrepancy between loans and bonds has become untenable as a doctrinal matter, the absence of pressure to correct from either market participants or regulators suggests that, contrary to all expectations, little may turn on the balance.

231. Id. at 5 .

232. See Standard \& Poor's, High Yield Bond Primer, supra note 112 (noting that only a small (albeit growing) percentage of $144 \mathrm{~A}$ high-yield bond issuances are "144A-for-life," that is, not subject to registration rights). 
Copyright of Journal of Corporation Law is the property of University of Iowa, College of Law (Journal of Corporation Law) and its content may not be copied or emailed to multiple sites or posted to a listserv without the copyright holder's express written permission.

However, users may print, download, or email articles for individual use. 